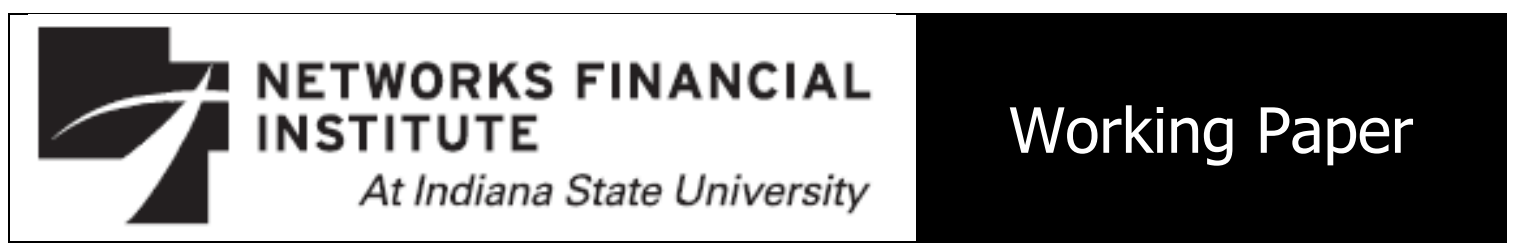

2018-WP-01 - January 2018

Discretionary loan-loss provision behavior in the US Banking Industry

\author{
Viet-Dung Tran, M. Kabir Hassan, and Reza Houston
}

Abstract: Earnings management can be either opportunistic, adding noise to reported earnings, or informative about a firm's underlying economic performance, adding valuable information to financial reports. This study examines earnings management in banks with differing levels of information asymmetry. Specifically, we compare earnings management between public and private banks by using discretionary loan-loss provisions (DLLPS) as proxies. Employing a large dataset of US public and private banks from 1986:Q1 to 2013:Q4, this study provides evidence of stronger earnings management behavior in public banks versus private banks. The evidence remains robust under a battery of sensitivity tests. Since incentives for earnings management are more relevant within a specific context, we identify the conditions that motivate different earnings management incentives, which allows us to better observe specific managerial motives. Greater DLLPs observed in public banks are utilized to send private information to investors, consistent with the signaling hypothesis. We also find evidence that capital requirements alter DLLPs, consistent with the capital management hypothesis. Banks with relatively low (high) earnings tend to decrease (increase) their earnings through manipulation of DLLPs, inconsistent with our income-smoothing hypothesis. The study extends to current debates on earnings management between public and private firms, and also provides a better understanding of the determinants of earnings management.

About the Authors: Viet-Dung Tran is affiliated with the Center for Studies and Applied Research in Management (CERAG) and Université Grenoble Alpes. He pursues research on the capital structure of Vietnamese banks. M. Kabir Hassan is Professor of Finance in the Department of Economics and Finance in the University of New Orleans. He currently holds two endowed Chairs-Hibernia Professor of Economics and Finance, and Bank One Professor in Business- in the University of New Orleans. Professor Hassan is the winner of the 2016 IDB Prize in Islamic Banking and Finance. Professor Hassan received his M.A. in Economics and Ph.D. in Finance from the University of Nebraska-Lincoln, USA respectively. Reza Houston is Assistant Professor of Finance and the Research Director of the Networks Financial Institute. Reza holds a Ph.D. in finance from the University of Missouri, and an MBA from Indiana State University. He has served as a journal referee, presented numerous papers, and acted as a discussant at international conferences. He currently maintains research interests in the role of the political economy, credit risk, and mergers and acquisitions.

Keywords: bank listing status; discretionary loan loss provisions; earnings management.

JEL classification: G21, G28, G34, G38

The views expressed are those of the individual author and do not necessarily reflect official positions of Networks Financial Institute. Please address questions regarding content to Viet-Dung Tran at viet-dung.tran@upmfgrenoble.fr. Any errors or omissions are the responsibility of the author.

NFI working papers and other publications are available on NFI's website (www.networksfinancialinstitute.org). Click "Publications" 


\title{
Discretionary loan-loss provision behavior in the US Banking Industry
}

\author{
Viet-Dung Tran \\ Univ. Grenoble Alpes \\ viet-dung.tran@upmf-grenoble.fr

\section{Kabir Hassan} \\ University of New Orleans \\ kabirhassan63@gmail.com \\ Reza Houston \\ Indiana State University \\ Reza.houston@indstate.edu
}

January 20, 2018 


\title{
Discretionary loan-loss provision behavior in the US Banking Industry
}

\begin{abstract}
Earnings management can be either opportunistic, adding noise to reported earnings, or informative about a firm's underlying economic performance, adding valuable information to financial reports. This study examines earnings management in banks with differing levels of information asymmetry. Specifically, we compare earnings management between public and private banks by using discretionary loan-loss provisions (DLLPs) as proxies. Employing a large dataset of US public and private banks from 1986:Q1 to 2013:Q4, this study provides evidence of stronger earnings management behavior in public banks versus private banks. The evidence remains robust under a battery of sensitivity tests. Since incentives for earnings management are more relevant within a specific context, we identify the conditions that motivate different earnings management incentives, which allows us to better observe specific managerial motives. Greater DLLPs observed in public banks are utilized to send private information to investors, consistent with the signaling hypothesis. We also find evidence that capital requirements alter $D L L P$ s, consistent with the capital management hypothesis. Banks with relatively low (high) earnings tend to decrease (increase) their earnings through manipulation of DLLPs, inconsistent with our income-smoothing hypothesis. The study extends to current debates on earnings management between public and private firms, and also provides a better understanding of the determinants of earnings management.
\end{abstract}

JEL Classification Codes : G21, G28, G34, G38

Keywords: bank listing status; discretionary loan loss provisions; earnings management. 


\section{Introduction}

Are publicly traded banks more likely to manage earnings than privately held banks? Does listing status increase the likelihood a bank will report numbers reflecting managerial discretion as opposed to the underlying economics (Levitt, 1998)? Knowledge of the answer to this question has been limited thus far, which is surprising given the important role of banks in the economy. To the best of our knowledge, only Beatty and Harris (1999), Beatty, Ke, and Petroni (2002), and Nichols, Wahlen, and Wieland (2009) provide evidence on the difference in accounting quality between public and private financial institutions. Consequently, this study aims to clarify the relationship between listing status and earnings management by using a large sample of public and private U.S. commercial banks.

One may argue that public banks should have greater incentives to manage earnings than private banks (Beatty and Harris, 1999), either to reduce the information content of earnings and obscure banks' fundamentals, or to increase the informativeness of the reported numbers by revealing banks' private information to stakeholders. Greater information asymmetry derived from a diffused ownership structure and greater capital market pressures would incentivize public bank managers to manage their financial statements to a greater extent. However, earnings management could be viewed as a vehicle for managers to convey their private information about their firms' situations. Greater demand by outside investors who suffer high barriers to internal information for high-quality information would lead public banks to "adjust" their accounts more to reveal additional information about the banks' future prospects.

In this paper, we conduct a two-stage approach to evaluate the impact of listing status on the earnings management of U.S. banks. First, we measure banks' earnings management, using loan loss provisions (LLPs). These items are by far the most critical accruals adjusted by banks (Beatty and Liao, 2014) and are typically large relative to net income and equity capital (Healy and Wahlen, 1999). Due to high dependence on the judgment of managers, LLPs reflect information asymmetry. Compared to prior studies that use pooled samples of industrial firms, the measure of earnings management in a single industry such as banking is more accurate due to the homogeneous sample composition (accounting, disclosure regulation, etc.), attenuating the bias due to measurement errors. We use the preferred model of Beatty and Liao (2014) in our main analysis. This model allows us to better separate normal LLPs, which are supposed to capture all adjustments reflecting banks' fundamental performance from the DLLPs that are due 
to managerial discretion. This unexplained portion of LLPs reflect the degree of earnings management. A greater unexplained component implies a greater degree of earnings management.

In the second stage, we examine the effects of listing status on earnings management for a large sample of 5,036 public banks and 14,177 private banks from 1986:Q1 to 2013:Q4. Our empirical analysis provides consistent evidence of greater earnings management through $D L L P \mathrm{~s}$ of public banks versus private banks.

To ensure the strength of our findings, we provide a battery of sensitivity tests. First, we address potential endogeneity in the decision to go public, which is a deliberate decision by bank managers. We begin with the matching procedures, with size-based matching and propensity score matching, to dissipate potential explanations that our findings reflect differences in the characteristics of public and private banks. Then we use the Heckman two-step model and an instrumental variables approach to extract the private information of the decision to go public that could be correlated with the propensity to use discretion in financial reporting. In all specifications, our findings remain unchanged.

Second, we rerun our model with alternative measures of earnings management. We begin by using different models to measure DLLPs. We also use gains and losses in discretionary securities. Our results confirm the stronger incentives to manage earnings in public banks versus private banks.

Third, we investigate whether listing status affects banks' earnings management differently during financial crises or not. We identify two banking crises and three market crises from 1986:Q1 to 2013:Q4. Our results suggest that public banks are less likely to manage their accounts during a market crisis, whereas they are more likely to increase their DLLPs during banking crises.

Having established how earnings management behavior differs between public and private banks, and documenting greater DLLPs of public banks, we next examine how corporate governance within public banks impacts earnings management behavior. The results indicate better-governed public banks exhibit higher DLLPs than less well-governed public banks. This finding suggests that public banks' pronounced incentives to manage earnings may be partially explained by agency problems. We further examine incentives which lead to different earnings management behavior between public banks and private banks. Since earnings management 
incentives are more relevant for a specific decision made by a specific decision maker (Dechow, Ge, and Schrand, 2010; Bushman and Williams, 2012), we identify different conditions that motivate different discretionary behaviors, which allows us to better observe specific managerial motives. Specifically, we hypothesize that (i) banks with large changes in future cash flow are more likely to signal their private information (signaling hypothesis); (ii) banks with currently high and low pre-managed earnings are more likely to smooth income (income-smoothing hypothesis); and (iii) banks with low regulatory capital ratios are more likely to manage capital (capital management hypothesis).

We find public banks with strong perceptions of their own financial strength are more likely to manipulate their LLPs than private banks with the same perceptions of their financial strength, consistent with the signaling hypothesis. We find banks with current earnings with relatively low (high) current earnings manage LLPs downward (upward), inconsistent with our income-smoothing hypothesis. ${ }^{1}$ We find public banks with high incentives for capital management are more likely to manage their accounts than private banks with the same incentives, consistent with our capital management hypothesis.

Our study contributes to the literature in several ways. First, our study extends the currently limited and conflicting debate on earnings management between public and private firms. We document greater earnings management in public banks than private banks, consistent with the findings of Beatty and Harris (1999), Beatty, Ke, and Petroni (2002), and Givoly, Hayn, and Katz (2010). However, this is not consistent with other studies such as Ball and Shivakumar (2005), Burgstahler, Hail, and Leuz (2006), Kim and Yi (2006), and Hope, Thomas, and Vyas (2013). ${ }^{2}$ Our study focuses on banking firms which belong to a highly regulated industry, in contrast with other studies which use non-financial industries and exclude regulated industries. ${ }^{3}$ Regulatory reporting and other regulations (e.g. capital requirement, deposit insurance schemes, business lines restrictions, etc.) are similar for both public and private banks in our sample,

\footnotetext{
${ }^{1} \mathrm{We}$ also test with alternative proxies for income smoothing incentives such as banks with high deviation from (earnings) average of industry or banks with high earnings volatility and high or low earnings. The findings remain unchanged.

${ }^{2}$ Hope, Thomas, and Vyas (2013) also find that, in some circumstances, public firms are more likely to act opportunistically by managing earnings. Public firms also face reduced demand for information, which leads to lower accrual quality.

${ }^{3}$ Beatty and Harris (1999) and Beatty, Ke, and Petroni (2002) use U.S. sample banks. The sample in Givoly, Hayn, and Katz (2010) includes two types of public companies: publicly traded equity and privately held equity which have publicly traded debt.
} 
reducing the cross-sectional heterogeneity. This is in contrast to private non-financial firms. By limiting the sample to a single industry within a single country, our result is not affected by unobservable differences in the underlying earnings reporting process across different industries, differences in accounting rules, or other differences in the institutional environment. Imposing these limitations makes our evidence stronger, cleaner, and more robust. ${ }^{4}$ Additionally, using single-country data alleviates the endogeneity issue associated with cross-border research, since the decision to go public or private and the financial reporting quality could be jointly determined by country- and institutional-level characteristics such as securities regulations and disclosure rules (Kim and Yi, 2006). Furthermore, by using a large sample lasting from 1986:Q1 to 2013:Q4, our evidence is not biased by sample selection, which could lead to opposing results. ${ }^{5}$ This paper also documents differential earnings management propensities of public versus private banks during crisis period which are not investigated in prior literature.

Finally, by identifying the variety of settings that could motivate different reporting behaviors between public and private banks, this study provides a better understanding of the determinants of earnings management in general. Our evidence highlights the complexity of the connections between discretionary behaviors to manipulate accounting statements and equity ownership structure. Both of these are conditional on different contextual and conjectural factors. The next section provides the hypothesis framework. Section 3 describes the data and measures of DLLPs and other variables. Section 4 reports the main results. We provide a battery of robustness tests in sections 5 and 6 . Section 7 provides potential explanations of higher earnings management incentives in public banks. Section 8 concludes the study.

\section{Why might public and private banks be different in earnings management behaviors?}

Managerial discretion in the financial statements can be attributed to either the desire to increase the wealth of total contracting parties or the desire to redistribute the wealth among the parties. If the discretion benefits ex-post the wealth of managers at the expense of other contracting parties, we can argue the managers have acted opportunistically. One may argue that public banks should have greater incentive to manage their earnings than private banks (Beatty and Harris, 1999),

\footnotetext{
${ }^{4}$ Dechow, Ge, and Schrand (2010) recognize the complexity of earnings quality measurement depends both on firms' financial performance and on their accounting systems.

${ }^{5}$ Ahmed, Takeda, and Thomas (1999) do not find evidence of the signaling hypothesis, in contrast with Wahlen's (1994) study, which suggests that the difference in their results is due to the difference in time period of study.
} 
either to reduce the informational content of earnings and obscure banks' fundamentals, or to increase the informativeness of earnings by revealing banks' private information.

\subsection{Opportunistic earnings management}

Diffused ownership structure, commonly observed in public banks, can mitigate shareholders' incentives to monitor managers' actions. Diffused owners are more likely to adopt rational apathy. They remain passive when a sole owner monitors management (Black, 1992). Owing to the collective action problem, diffused shareholders bear the full costs of monitoring (e.g., the costs of storing, retrieving, and processing information) whereas they derive a limited share of gains from monitoring. Therefore, shareholders in public banks are more likely to use simple low-cost heuristics such as earnings-based benchmarks to assess banks' performance (Burgstahler and Dichev, 1997; Beatty, Ke, and Petroni, 2002). In contrast, private shareholders have lower marginal costs of retrieving information, and reap a higher fraction of the benefits, suggesting that they are more likely to use fairly rich information, rather than relying on a simple earnings-based benchmark (Beatty, Ke, and Petroni, 2002). It is suggested that public banks should have greater incentives to manage their accounts than private banks.

Second, pressures from capital markets may have potential countervailing effects on incentives to report high-quality earnings. The reliance of investors on accounting information to evaluate short-term performance motivates public bank managers to manage accounting numbers (Graham, Harvey, and Rajgopal, 2005). Moreover, managers of public banks have greater incentives to "adjust" earnings to meet or beat analysts' or investors' expectations (Degeorge, Patel, and Zeckhauser, 1999; Bartov, Givoly, and Hayn, 2002), or to avoid reporting reduced earnings or losses (Burgstahler and Dichev, 1997; Beatty, Ke, and Petroni, 2002). These earnings manipulations aim to avoid market penalization (Skinner and Sloan, 2002), to build credibility from markets, or to increase stock performance (Bartov, Givoly, and Hayn, 2002; Graham, Harvey, and Rajgopal, 2005). Studies also suggest that managers of public firms manage accounting numbers to influence earnings expectations of specific investors such as institutional investors with high portfolio turnover and high momentum trading (Bushee, 1998). Even though private bank managers may engage in opportunistic behavior to impair reporting quality, ${ }^{6}$ they

\footnotetext{
${ }^{6}$ Dichev et al., 2013 note that in order to avoid violating debt covenants or meet performance expectations, there is greater emphasis on contractual considerations. The lack of stock liquidity also mitigates the short-termism in private banks (Ferreira, Manso, and Silva, 2014).
} 
do not face the same pressures from the market since they rely primarily on loans from banks and/or private lenders. As a result, private banks likely have weaker incentives to manipulate financial reports.

A third reason for greater earnings manipulation in public banks is related to the bonus hypothesis (Healy, 1985; Bergstresser and Philippon, 2006). Since the personal wealth of public banks' managers is positively correlated with stock valuation as a result of their stock ownership or stock-based compensation, these managers are more likely than managers of private banks to manage earnings.

Finally, public banks are more likely to manage earnings during periods surrounding capital market transactions. In a management buy-out, managers are more likely to understate earnings in order to portray an unfavorable picture of their firms' perspective, and consequently obtain a favorable purchase price (DeAngelo, 1988), whereas firms tend to practice incomeincreasing earnings management around a merger (Christie and Zimmerman, 1994). Public firms are more likely to overstate earnings prior to initial public offers (Teoh, Welch, and Wong, 1998) and seasoned equity offers (Teoh, Welch, and Wong, 1998).

These arguments suggest that public banks have greater incentives to manage their accounts opportunistically than private banks. Such earnings management adds noise to reported earnings either to delude the financial report's users about the true economic performance of firms or to get greater benefits from contractual outcomes (Healy and Wahlen, 1999).

\subsection{Signaling incentives}

The literature suggests that earnings management is a vehicle for managers to convey their private information to outsiders (Wahlen, 1994; Beaver and Engel, 1996; Bushman and Williams, 2012). This signaling view is based on the assumption that investors could observe and value the changes in reported earnings. Private banks are supposed to have less incentive to signal good news to shareholders than public banks, because private banks are closely held by a few shareholders who have a close relationship with management (Fama and Jensen, 1983). The fact that (i) private shareholders' turnover is lower, (ii) private shareholders can directly monitor management and have insider access to corporate information, and (iii) private shareholders have weaker incentives to evaluate banks continuously due to reduced agency costs and little reliance on financial statements for monitoring private banks' managers. Furthermore, private banks are 
more likely than public banks to communicate privately, on an "as-needed" basis, with stakeholders (Ball and Shivakumar, 2005).

\subsection{Related research}

Empirical findings provide mixed evidence on the earnings management of public versus private firms. Burgstahler, Hail, and Leuz (2006) show private firms exhibit greater earnings management in an international sample from 13 EU countries. Hope, Thomas, and Vyas (2013) find that U.S. public firms have less incentive to manage their accounts than private firms.

In contrast, studies have concluded that public firms have greater incentives to manage earnings than private firms. In an early study, Penno and Simon (1986) examine questionnaires mailed to US private and public firms and find public firms are more likely to choose incomeincreasing accounting than are private firms. Givoly, Hayn, and Katz (2010) document that publicly held equity firms have lower-quality accruals and are more likely to manage earnings to meet or beat the earnings thresholds than firms with privately held equity. In the same vein, Smith (1976) and Bowen, Noreen, and Lacey (1981) indicate that manager-controlled firms, which are more likely to be public firms, use more discretionary accounting than ownercontrolled firms. Kim and Yi (2006) document that Korean public firms are more aggressive in managing earnings than private firms.

Regarding empirical research related to banking firms, Beatty and Harris (1999) find significantly greater earnings management for public banks. Beatty, Ke, and Petroni (2002) show public banks are more likely than private banks to manipulate earnings to avoid small earnings declines, whereas Nichols, Wahlen, and Wieland (2009) find that public banks behave more conservatively than private banks.

In brief, the existing research draws contentious conclusions about the difference in the quality of financial reporting between public and private banks. This study aims to add to the stream of research by providing evidence from a large sample of US banks.

\section{Data, and variables}

\subsection{Sample banks}

The Federal Reserve provides quarterly Call Reports (Report of Condition and Income) for all commercial banks starting with 1986:Q1. Our sample begins in 1986:Q1 since many banks 
provided semiannual reports rather than quarterly data prior to $1986:$ Q1. ${ }^{7}$ Our raw data covers the period from 1986:Q1 to 2013:Q4, and initially contains 1,211,520 bank-quarter observations. We drop all non-commercial banks, resulting in 1,078,014 remaining observations. Next we remove any bank-quarter observations with missing or incomplete financial data on basic accounting variables of the main model of regression. Following Berger and Bouwman (2013), we replace all observations with a shareholder equity ratio less than $1 \%$ with $1 \%$ to avoid distortion in ratios that contain equity. All other financial ratios have been winsorized at the $1 \%$ and $99 \%$ levels to dampen the effects of outliers. We also exclude observations with (i) gross total assets less than or equal to $\$ 25$ million, or (ii) negative or no outstanding loans or deposits. Our final dataset contains 846,947 observations from 15,976 commercial banks.

\subsection{Measures of bank earnings management}

We use the residuals from the LLPs estimations model as a proxy of bank earnings management. LLPs estimations are based on judgments of bank managers and reflect the expected losses of originating and holding loans during the period; thus, LLPs are vulnerable to manipulation. However, not all LLPs are subject to manipulation since some parts of LLPs are appropriately adjusted on a regular basis.

LLPs can be classified into two categories: (i) non-discretionary LLPs and (ii) discretionary LLPs (DLLPS). The challenge is how to shape a relevant underlying model to capture LLP characteristics, which in turn allows us to isolate DLLPs from the estimation of nondiscretionary LLPs. The estimated DLLPs should only represent the amount of additional adjustments to the LLPs based on different incentives of managers' discretion.

In their extensive review of accounting in the banking industry, Beatty and Liao (2014) state that there is no consensus in banking studies on how best to model discretionary provisions ${ }^{8}$ and discretionary accrual estimates. Following Jiang, Levine, and Lin (2016), we use the Beatty and Liao (2014) preferred model. $^{9}$

\footnotetext{
${ }^{7}$ Call Report data in the Federal Reserve database begins in 1976:Q1.

${ }^{8}$ The non-bank literature usually uses the Jones-type model. The two most popular models are the cross-sectional Jones model (Jones, 1991) and the modified Jones model (Dechow, Sloan, and Sweeney, 1995).

9 There are four models in Beatty and Liao (2014). The difference between this model and the other three models is the simultaneous inclusion of the (lagged) allowance for loan losses $\left(a l w_{i t-1}\right)$ and the net charge-off $\left(c h o_{i t}\right)$, which allows researchers to better capture the underlying behavior of LLPs. The loan-loss allowance reflects the value of loans the bank estimates to be uncollectable. The inclusion of initial loan-loss allowance aims to control any over(under-) accrual present at the beginning of the current quarter which would require downward (upward) adjustment
} 


$$
\begin{gathered}
l l p_{i t}=\alpha+d n p l_{i t+1}+d n p l_{i t}+d n p l_{i t-1}+d n p l_{i t-2}+\operatorname{alw}_{i t-1}+\text { cho }_{i t}+\text { size }_{i t} \\
+ \text { dloan }_{i t}+\text { csret }_{i t}+d g d p_{i t}+\text { dunemp }_{i t}+\epsilon_{i t}
\end{gathered}
$$

The use of this LLP process model allows us to separate normal LLPs, which are supposed to capture all adjustments reflecting banks' performance fundamentals, from DLLPs. DLLP's are represent the deviation from performance fundamentals. The estimation of nondiscretionary LLPs is based on the practice of loan-loss accounting and the external environment. If the normal component of LLPs is properly estimated, then the discretionary component represents distortions from the application of accounting rules or earnings management. These distortions could either lower reporting quality (Dechow, Ge, and Schrand, 2010) or reflect managers' private information (Wahlen, 1994).

In Equation (1), $d_{n p l} l_{i t}$ represents the change in non-performing loans (NPL), normalized to the beginning of total loan of bank $i$ at time $t$. Since the changes in NPL are leading indicators of potential future loan losses and are likely to be serially correlated (Beaver et al., 1989), we employ the change in non-performing loans from the current quarter to the next quarter $\left(d n p l_{i t+1}\right)$ to take into account the use of forward-looking information by banks when estimating their LLPs. The leading variable $\left(d n p l_{i t+1}\right)$ indicates unreported information management has at time $t$ about the future default exposure of bank loans. This is in contrast to the concurrent $\left(d n p l_{i t}\right)$ and lagged $\left(d n p l_{i t-1}\right)$ changes in NPL, which capture previously observed changes in portfolio performance and ultimate collectability (Bushman and Williams, 2012; Beatty and Liao, 2014). The change in loans, dloan $i t$, is included to measure the effects of the changes of loan portfolios on quality of loan and non-discretionary changes in earnings (Beatty, Ke, and Petroni, 2002). The Case-Shiller return index $\left(\right.$ csret $\left._{i t}\right)$, the change in unemployment rate $\left(\right.$ dunemp $\left._{i t}\right)$ and the GDP growth rate $\left(d g d p_{i t}\right)$ are included to take into account the effects of the macroeconomic environment on the quality of loan portfolios, even though the change in non-performing loans and loan charge-offs takes into account to some extent the macroeconomic effects (Kanagaretnam, Lobo, and Yang, 2004).

Once the model (1) is estimated, we use the forecasted value to estimate the nondiscretionary LLPs. DLLP is calculated as the prediction error of this regression. By including

of LLPs during the current period (Kanagaretnam, Krishnan, and Lobo, 2010; Beck and Narayanamoorthy, 2013). Net charge-offs, contrary to LLPs, represent defaults on loans held during the period. Since current net charge-offs reflect information of future net charge-offs, they can in turn influence expectations of the collectability of current loans and current LLPs (Beaver and Engel, 1996). 
the previously-identified nondiscretionary variables, Equation (1) is a parsimonious model reflecting management's judgment of a non-discretionary component of LLPs and a discretionary component of LLPs.

Negative (positive) DLLPs indicate negative (positive) deviations from LLPs, which suggest managers could be overstating (understating) earnings to conceal resource deviation. Positive DLLPs in high-performance periods are sometimes described as creating a "cookie jar" reserve for poor performance in the future. We use both positive and negative residuals, and compute their absolute values for easy interpretation. Higher (absolute) values of DLLPs indicate that banks exhibit greater discretionary behavior. For estimations, we use both unsigned (absolute value of negative and positive DLLPs) and signed DLLPs to provide a more thorough analysis of banks' discretionary behavior. ${ }^{10}$ Following Jiang, Levine, and Lin (2016), we use the natural logarithm of the absolute value of DLLPs.

\subsection{Control variables}

In order to mitigate a potential omitted variable bias, we control for various bank-specific variables, as well as bank fixed effects and time (quarters) fixed effects. The use of bank and time fixed effects is consistent with previous literature (Bushman and Williams, 2012). The bank-specific control variables are described below.

First, we control for the size effect by using the natural logarithm of the book value of gross total assets. Large banks tend to have more stable operations and a greater ability to diversify risks. We expect large banks to report smaller amounts of DLLPs (Dechow and Dichev, 2002), whereas small banks are more likely to have internal control deficiencies and a greater propensity to correct previously reported earnings (Doyle, Ge, and McVay, 2007). Furthermore, larger banks might be subject to more stringent regulatory scrutiny and monitoring (Beatty and Liao, 2014).

Second, we control for the leverage effect by using the ratio of total equity over the gross total assets (shareholder equity ratio). Banks with lower equity ratios have greater incentive to

\footnotetext{
${ }^{10}$ Prior literature in the accrual-based approach usually tests for a particular sign (see, e.g., DeFond and Jiambalvo, 1994; Dechow, Sloan, and Sweeney, 1995; Teoh, Welch, and Wong, 1998), whereas recent research uses unsigned measures to "detect" which firms are more likely to use discretion in accounting in the absence of a precise direction (see, e.g., Dechow and Dichev, 2002; Frankel, Johnson, and Nelson, 2002; Leuz, Nanda, and Wysocki, 2003). The use of signed DLLPs allows us to observe the directional DLLPS within a specific reporting context and incentive structure (Francis, Olsson, and Schipper, 2006).
} 
manage reported earnings, due to concerns about debt covenant violations (Kim and Yi, 2006). Managing reported earnings could also improve their reserve bargaining power by reducing the perceived risks of creditors (Watts and Zimmerman, 1986). In addition, highly leveraged banks are more likely to use discretion in their financial reporting to present an improved picture for existing and potential shareholders (Penman, Richardson, and Tuna, 2007). However, Barton and Waymire (2004) suggest that highly leveraged banks are less likely to manage their accounts due to the increase of agency costs of debt.

Third, previous research has documented the importance of performance on LLPs. Poorly-performing firms are more likely to use accounting discretion to boost income (Doyle, $\mathrm{Ge}$, and McVay, 2007). We include two indicators of performance in our model. First, we use an indicator of loss, equal to 1 if a bank experiences negative income in the current quarter, and 0 otherwise. Second, we calculate premanaged earnings, which are the earnings before taxes and LLPs over the gross total assets.

Finally, a tougher regulatory environment could lead to reduced incentives and opportunities for discretionary LLPs (Warfield, Wild, and Wild, 1995). We control for the effects of the regulatory environment by including FED and OCC dummy variables that equal 1 if a bank is a state-chartered Federal Reserve System member or has a national bank charter, respectively. Banks which are primarily regulated by the FDIC receive scores of 0 for both the FED and $O C C$ variables.

Table (2) reports the summary statistics of our firm-specific variables. On average, public banks are larger but hold less capital (both in leverage and Tier 1 ratio) than private banks. Public banks are also more profitable and experience lesser losses on average than private banks. ${ }^{11}$

\section{Does listing status affect discretionary LLPs' behavior?}

\subsection{Main findings}

Our main econometric model tests the relation between DLLPs and bank listing status. The empirical specification we estimate is as follows:

\footnotetext{
${ }^{11}$ In an unreported test, we find that all these differences are significant at $1 \%$.
} 
$Y_{i t}=\alpha+$ listing $_{i t}+Z_{i t}+\delta_{i}+\theta_{t}+\varepsilon_{i t}$

where $Y_{i t}$ is the measure of DLLPs of bank $i$ at time $t$, described in section 3.2. Our variable of interest is listing, which takes a value of 1 if bank $i$ is listed at quarter $t$, and 0 otherwise. $Z_{i t}$ is the vector of control variables described above. We include bank-fixed effects, $\delta_{i}$, to control for unobservable banks characteristics, and time-fixed effects, $\theta_{t}$, to control for time effects, both of which can affect the discretionary behaviors of banks. $\varepsilon_{i t}$ is the error term. Since DLLPs are likely to be correlated within a bank over time, standard errors used to assess significance are corrected for heteroscedasticity and bank-level clustering.

Our main results from the multivariate analysis are shown in Table (3). Models (1)-(3) report the results of unsigned DLLPs, Models (4)-(6) report the results of negative DLLPS (NDLLPs) (absolute value), and Models (7)-(9) report the results of positive DLLPs (PDLLPs). In our baseline model (1), the coefficient on listing status is positive, indicating that public banks are more likely to manage their financial reporting than private banks. The results in our baseline model persists when we restrict our sample to positive DLLPs (Model (4)) and negative DLLPs (Model (7)) These results indicate public banks are more likely than private banks both to increase and to decrease DLLPs. These findings confirm the evidence of Beatty and Harris (1999) and Beatty, Ke, and Petroni (2002). ${ }^{12}$ The results indicate that DLLPs of public banks are $10.8 \%$ larger than those private banks (Model (1)). With signed DLLPs, we find that public banks have absolute negative (positive) DLLPs 13.7\% (8.1\%) greater than private banks.

Although we include control variables identified in literature in our baseline model, there may exist some omitted and correlated variables. In Models (2) and (3), we extend our baseline model (1) by controlling for the effect of growth opportunities as measured by the growth of assets and net interest income. We also include macro-economic variables, which are at least as important as other discretionary factors (Dichev et al., 2013). Again, we observe in all models that public banks experience higher discretionary LLPs than private banks.

Regardless of the control variables, we observe that large banks are more likely to engage in LLPs management, which runs counter to what we expect. A potential explanation is large banks are more skilled at manipulating earnings. The evidence also shows that well-capitalized

\footnotetext{
${ }^{12}$ One may argue that there is a change in bank financial reporting with SFAS 115 that became effective end of 1993 and early 1994. Those are transition years. After 1994, reports are not comparable to 1992 and before. We then re-run the analysis on data from 1994:Q1 to 2013:Q4, and find similar results.
} 
banks are more likely to engage in LLP management. However, the coefficient on capital ratio is not statistically significant. Profitable banks and banks that encounter losses are more likely to use discretion in financial reporting. We do not find evidence of effects of regulation on discretionary behavior of banks. Additionally, high-growth banks tend to engage more in LLP management, and favorable economic conditions allow a decrease in DLLPs.

\subsection{Alternative samples}

In Table 4, we re-conduct our baseline model with alternative samples. In Models (1)-(3) we report results using a balanced panel (excluding banks that only existed during part of the sample period). This exclusion mitigates the effects of M\&A activities and bank defaults on our investigation, though at the price of over-representing "successful" banks. Our results in Models (1)-(3) show the coefficients of listed indicators remain positive and statistically significant for all specifications. Next we re-estimate the model at the bank holding company level. Consistent with our other findings, publicly traded banks exhibit greater DLLPs. As a final robustness check, we perform our tests at the annual level in Models (7)-(9). Because banks cannot continuously have positive (or negative) DLLPs indefinitely, the use of annual data should attenuate our results. We note a positive and statistically significant coefficient with NDLLPs, but the listing status become marginally significant for the entire sample (Model (7)) and PDLLPs (Model (9)). The results reflect the fact that managers of public banks have stronger incentive than managers of private banks to manage DLLPs downward to inflate earnings.

\subsection{Alternative measures of earnings management}

In this section, we use alternative proxies to measure earnings management. We document our results in Table 5. First, we use the three alternative models detailed in Beatty and Liao (2014). We re-estimate these three models, then separate DLLPs from non-discretionary LLPs. Next, we re-estimate our main model. The results are shown in Models (1)-(3).

$$
\begin{aligned}
& l l p_{i t}=\alpha+d n p l_{i t+1}+d n p l_{i t}+d n p l_{i t-1}+d n p l_{i t-2}+\operatorname{size}_{i t}+\text { dloan }_{i t}+\operatorname{csret}_{i t} \\
& +d g d p_{i t}+\text { dunemp }_{i t}+\epsilon_{i t} \\
& l l p_{i t}=\alpha+d n p l_{i t+1}+d n p l_{i t}+d n p l_{i t-1}+d n p l_{i t-2}+\operatorname{size}_{i t}+d l o a n_{i t}+a l w_{i t-1} \\
& + \text { csret }_{i t}+d g d p_{i t}+\text { dunemp }_{i t}+\epsilon_{i t}
\end{aligned}
$$




$$
\begin{gathered}
l l p_{i t}=\alpha+d n p l_{i t+1}+d n p l_{i t}+d n p l_{i t-1}+d n p l_{i t-2}+\operatorname{size}_{i t}+d \operatorname{doan}_{i t}+\text { cho }_{i t} \\
+ \text { csret }_{i t}+d g d p_{i t}+\text { dunemp }_{i t}+\epsilon_{i t}
\end{gathered}
$$

Prior literature indicates that real activities like realized securities gain and losses (RSGL) are also subject to earning manipulation (Scholes, Wilson, and Wolfson, 1990; Collins, Shackelford, and Wahlen, 1995; Beatty and Harris, 1999; Beatty, Ke, and Petroni, 2002). Following Beatty, Ke, and Petroni (2002), we use the following model to estimate the nondiscretionary proportion of RSGL:

$$
r s g l_{i t}=\operatorname{size}_{i t}+\operatorname{ursgl}_{i t}+\varepsilon_{i t}
$$

where $r s g l_{i t}$ represents the realized securities gain and losses of bank $i$ at time $t$, and $u r s g l_{i t}$ represents the unrealized securities gain and losses of bank $i$ at time $t$. The residual from Equation (6) is taken as the discretionary component of RSGL.

Since earnings decrease with DLLPs and increase with discretionary rsgl (dsrgl), we measure the net effect of banks' discretionary earning as the difference between a bank's $d r s g l_{i t}$ and dllps st $^{2}$

$$
\operatorname{dearn}_{i t}=\operatorname{drsgl}_{i t}-\text { dllps }_{i t}
$$

We then re-estimate Equation (2) with these two measures as dependent variables. The results are shown in Models (4)-(5) and confirm previous finding on the weaker discretionary behavior through LLPs of private firms. ${ }^{13}$

In sum, the basic OLS regression results suggest that, ceteris paribus, public banks manage earnings to a greater extent than private banks. These results hold even after controlling for a variety of bank-specific variables and after substantial modifications to the sample composition.

\section{Is the choice of being public endogenous?}

The specification in Equation (2) is based on the assumption that a bank's decision to go public is exogenous. However, research shows that listing status is endogenous and is a deliberate decision by bank managers. Our results may be derived from the unobservable differences between public and private banks that simultaneously affect the decision to go public/stay private and the earnings management behavior of banks. These unobservable differences could lead to

\footnotetext{
${ }^{13}$ One may argue that, with the adoption of SFAS 157 in 2007, banks have no more leeway to manage earnings through security sales. Thus, we re-estimate Equation (2) with the sample until 2007. The results are still robust.
} 
potential bias in the OLS framework. Thus, we complement our OLS estimation with different matching procedures: the Heckman selection model and the instrumental variable approach. These procedures should control for any selection bias that may be present in the above estimation. We report our results when the dependent variable is unsigned DLLP, though our results for signed DLLPs are quantitatively similar.

\subsection{One-to-one size-based matching}

We start our matching by using caliper-based nearest-neighbor matching adapted to a panel setting. Specifically, we match each public bank with the private bank closest in size. ${ }^{14} \mathrm{We}$ change the matched private banks only when the initial match exits the database, and keep the new match going forward.

The resulting matched sample includes 267,802 bank-year observations with 133,901 public bank-years and an equal number of private bank-years. ${ }^{15}$ Since the matching procedure is with replacement, the sample contains 5,036 public banks and 4,309 private banks. We then reestimate our baseline model, and find that public banks use more discretion in loan-loss accounting than size-matched private banks (Model (1), Table (6)).

\subsection{Propensity score matching}

One of drawbacks of this size-matching procedure is that the bank size is not always exactly matched, leading to substantial bias (Kai and Prabhala, 2007). The greater the overlap in size between public and private banks, the more comparable the groups and the smaller the bias. However, when we decrease the matching caliper, finding matches becomes more difficult or even impossible. In addition, there are many potential reasons that banks go public. Thus, partial matching based on one dimension would likely not yield the most accurate matched-bank sample. We therefore employ the propensity score matching (PSM) system developed by Rosenbaum and Rubin (1983) and extended by Heckman, Ichimura, and Todd (1997).

\footnotetext{
${ }^{14}$ We adopt the criterion common in the literature: $\frac{\max \left(\text { assets }_{\text {public }}, a_{\left.s s e t s_{\text {private }}\right)}\right.}{\min \left(\text { assets }_{\text {public }}, \text { assets } \text { private }\right)}<2$. Following Kothari, Leone, and Wasley (2005), we also use performance-based matching and get quantitatively similar results.

${ }^{15}$ We use the matching with replacement procedure, which produces a higher quality of match since it reduces the large difference in size between public and private banks. However, this procedure comes at the cost of reducing efficiency since fewer distinct observations are used.
} 
To conduct propensity score matching (PSM), we separate the full sample into two groups: public (treated) and private (untreated) banks. Next, we measure the propensity of undergoing treatment (i.e. the probability of going public) by using a logit model for both treated and untreated samples. Our dependent variable in this logit model is a binary variable which equals 1 if the bank goes public, and equals zero otherwise. ${ }^{16}$ Then, we match each public bank with one or more private banks sharing similar characteristics as reflected in their propensity scores. ${ }^{17}$ We initially use one-to-one matching with replacement, which allows each private bank to be used more than once. We also use one-to-one matching without replacement, which requires each private bank to be used exactly one time. We also match each public bank with the two and three private banks with the closest propensity scores. ${ }^{18}$ We present the results of our PSM analysis in Models 2-5, Table 6. The results are robust to different specifications of PSM. We observe that the magnitude of coefficients of listing status from PSM specifications is stronger than in our baseline model.

\subsection{Selection model for public versus private ownership}

The matching estimators presented above mitigate the selection bias. However, there may be unobservable factors that explain decisions to go public. We use the Heckman two-step approach to eliminate the bias due to unobservable variables. We first model the selection of public and private status by using the logit selection model, and then obtain the inverse Mills ratio (IMR) the omitted variable in Equation (2). The accounting literature (See, e.g., Ball and Shivakumar, 2005; Kim and Yi, 2006; Nichols, Wahlen, and Wieland, 2009) usually includes firm size, leverage, and growth in the logit listing-choice model as explanatory variables. Following Gao, Harford, and Li (2015), we add the state-level household stock market participation rate (stownr) with control variables defined in Equation (2). Households are more likely to hold shares of local public firms and tend to participate more in the stock market if many local firms are listed (Brown, Ivkovic, Smith, and Weisbenner, 2008). We also add other control variables as in

\footnotetext{
${ }^{16}$ We detail the first-stage in Section 5.3.

${ }^{17}$ We retain only untreated observations whose propensity scores fall inside the interval defined for the treated group. We impose a tolerance level of $0.5 \%$ on the maximum propensity score distance allowed (caliper), to minimize the risk of bad matches.

${ }^{18}$ Using this oversampling matching leads to a trade-off between bias and variance. Since more information is used to construct the counterfactual for each participant, leading to a decreased variance, it increases bias resulting from poorer matches.
} 
Equation (2). ${ }^{19}$ We then estimate the logit listing-choice model and calculate IMR. The IMR is the conditional expectation of the model selection error term, given the banks' observable characteristics and ownership status. In the second stage, we re-estimate Equation (2) by including IMR as an additional control variable to correct for potential self-selection biases. We also include the interaction term IMR*Listing to allow the variation of $I M R$ between public and private banks (Nichols, Wahlen, and Wieland, 2009), given that an omission of this interaction term does not change the result.

Model (1) in Table 7 reports the maximum likelihood estimates of the logit listing-choice. All coefficients are highly significant. Large, highly profitable, and high-growth banks are more likely go public, whereas well-capitalized banks tend to be private. Banks in states with high household stock market participation are more likely to raise equity capital by the stock market. Model (2) reports the second-stage model results. Consistent with our findings in Tables 3 to 6 , public banks exhibit greater DLLP.

\subsection{Instrumental variables approach}

We conclude our inquiry into endogeneity of listing status with an instrumental variables (IV) estimation. This estimation extracts the exogenous component of the listing status of banks. The instrument is the state-level household stock market participation rate (stownr) as documented in the preceding section. Greater state-level household stock market participation rate should incentivize managers to take their banks public since there is likely greater demand for those shares. At the same time, the state-level stock market participation rate is unlikely to be influenced by the performance or size of one particular firm.

We report the first-stage and second-stage IV regression results in Models (3) and (4) of Table 7. In Model (4) our IV is positively and significantly associated with listing status. This confirms the relevance of our IV. The result of second-stage supports the hypothesis that public banks manage their financial reports more than private banks. We observe that the coefficient of IV estimation is much larger in absolute value than the OLS estimate, which is consistent with our concern about the reverse causality and hence with the need to use IV to identify the impact

\footnotetext{
${ }^{19} \mathrm{We}$ also test for several variations of the first-stage model following prior research. First, we use lagged value of explanatory variables since one may argue that a bank's choice to go public is based on its underlying economics of the past year (Kim and Yi, 2006). We also add the components of loan portfolio as in Nichols, Wahlen, and Wieland (2009). Inclusion or exclusion of these variables has no qualitative effect on our results.
} 
of going public on account manipulation. The OLS estimation might yield coefficient estimates of the impact of listing status on accounts manipulation that are biased toward zero, whereas the IV estimation yields the more accurate (and larger) impact of listing status on bank manipulation behavior.

\section{Bank earnings management during financial crises}

We use the financial crises as a quasi-natural experiment to examine whether the difference in discretionary behavior between public and private banks changes under the effects of crises. Managers do more earnings management during financial crises in order to convey good news to markets and indicate the bank's ability to survive (Bartov, Givoly, and Hayn, 2002). Graham, Harvey, and Rajgopal (2005) show that CEOs are more likely to use discretion to boost the reported earnings and to delay the reversal of these actions until the cessation of the crisis. However, monitoring from external agents such as regulators is likely to increase during financial crises, leading to higher litigation risk and reduced incentives for managers to use discretion.

Following Berger and Bouwman (2013), we identify two banking crises (the credit crunch, 1990:Q1-1992:Q4, and the subprime crises, 2007:Q3-2009:Q4) and three market crises (the 1987 stock market crash, 1987:Q4; the Russian debt crisis/LTCM bailout, 1998:Q31998:Q4; and the internet bubble, 2000:Q2-2002:Q3). We first investigate whether there is a difference between earnings management of public and private banks during the financial crises by including the interaction term Listing*Fi_Crises in Model (1). In Models (2) and (3), we separately investigate this difference during each type of crisis (Listing*Bk_Crises and Listing*Mk_Crises, respectively). Finally, include collectively the interactions with both crisis dummies in Model (4). ${ }^{20}$ We re-estimate all specifications with NDLLPs (Models (5)-(8)) and with PDLLPs (Models (9)-(12)).

We do not observe a difference in discretionary behavior of public banks versus nonfinancial crisis periods during financial crises. While we still document a positive relationship between Listing and DLLP, the coefficient on the interaction term (Listing*Fi_Crises) is not significant (Model (1)). However, the estimations with signed DLLPs reveal interesting results.

\footnotetext{
${ }^{20}$ We do not use crisis dummies alone since they are subsumed by the time fixed-effects. However, replacing time fixed-effects with dummies of crises do not change our results.
} 
Specifically, public banks are less likely to decrease their LLPs through NDLLPs, as indicated by the negative coefficient of interaction term (Model (5)). In Model 9, we regress PDLLP on Listing, the interaction term, and firm-level controls. The positive interaction term indicates public banks are more likely to increase their LLPs through increased PDLLPs during crisis periods. Taken together, Models (5) and (9) indicate public banks are more likely to both increase and decrease their LLPs than private banks.

Next, we split our crises into banking crises and market crises as defined by the Federal Reserve. We split these events since each could have different implications for banks. In Models (2), (6), and (10) we employ include only the banking crisis indicator variable in our model. Consistent with our results in Model (1), we find public banks are more likely to increase their LLPs in absolute terms. The results in Models (6) and (10) indicate public banks increase the magnitude of both their NDLLPs and PDLPPs.

During market crises, public banks appear to decrease their use of DLLPs. We report our results in Models (3), (7), and (11). In Model (3) the interaction term between Listing and our indicator variable for market crises is negative, suggesting that public banks decrease the overall magnitude of the DLLPs they employ. In Models (7) and (11), we report the results of regressions where the dependent variable is NDLLP or PDLLP. The interaction term between Listing and Mk_Crises is negative in both models is negative and significant, indicating that public banks lower both their NDLLPs and PDLLPs to a greater extent than private banks during market crises. Our results remain consistent when we include both crisis dummies in Models (4), (8), and (12), although we only find marginal significance to support the hypothesis that public firms reduce PDLLPs in Model (12).

\section{Insight into different incentives of manipulation between public and private banks}

Having provided evidence that the DLLPs of public and private banks differ, we investigate whether the greater earnings management we document is due to opportunistic incentives, willingness to reveal private information about future prospects, capital requirements, or some combination of all three. One way to examine opportunistic behavior would be based on corporate governance issues; however, that is not possible due to the unavailability of data related to private banks. Therefore, we then investigate how, different qualities of governance impact discretionary behavior within public banks. 
We test the impact of governance on discretionary behavior of public banks by collecting data on managerial entrenchment. Following Bebchuk, Cohen, and Ferrell (2009), we construct an entrenchment index (E-index) and collect institutional ownership data for a subset of public banks. We posit that banks with low E-indexes and greater institutional ownership, block institutional ownership, and long-term institutional ownership will have superior corporate governance. This increase in corporate governance leads to fewer agency problems and weakens the discretionary power of managers. The results in Table 9 show that public banks with higher corporate governance quality (in the top quartile) manage their financial reporting of DLLPs to a greater extent than public banks with lower corporate governance quality (in the bottom quartile). The difference is significant regardless of whether we use signed or unsigned DLLPs. Our results indicate good governance and the correspondingly lower agency costs are associated with more discretionary behavior in our subset of public banks. In other words, this finding partially reveals that the incentives of earnings management from public banks can partially be explained by agency problems.

Next, we turn to examine different incentives leading to greater earnings management in public banks versus private banks. Since earnings management incentives are more relevant to a specific decision made by a specific decision-maker (Dechow, Ge, and Schrand, 2010; Bushman and Williams, 2012), we identify different conditions that motivate discretionary incentives. Doing so allows us to better observe specific managerial motives.

Our first test considers the signaling incentives in banks. Prior studies allege that bank managers use DLLPs as signaling devices to communicate their private information about the banks' future prospects to the markets. ${ }^{21}$ The idea behind this hypothesis is that banks with high confidence concerning favorable future earnings will have strong incentives to communicate to stakeholders by voluntary adopting accounting estimates to reduce earnings. One possible approach is to rely on DLLPs. By adjusting DLLPs upward, then reducing earnings, these banks would signal their belief that such earnings reduction will not negatively affect their ability to make future cash distributions (Kanagaretnam, Lobo, and Yang, 2004). The cost of sending the wrong signal would be high, since low-quality banks would face higher probability of

\footnotetext{
${ }^{21}$ See, e.g., Beaver et al. (1989), Wahlen (1994), Beaver and Engel (1996), Liu and Ryan (1995), and Liu, Ryan, and Wahlen (1997), who find positive stock price reactions when future cash flow prospects improve. In contrast, Ahmed, Takeda, and Thomas (1999) do not find support for the signaling incentives in banks, whereas Kanagaretnam, Lobo, and Yang (2004) find inconsistent evidence.
} 
intervention from bank regulators in case of reporting lower earnings (Collins, Shackelford, and Wahlen, 1995). ${ }^{22}$ Since it is easier for private banks to communicate with their arm's-length shareholders through private channels, we suspect that the positive association between DLLPs and listing status is heightened by higher incentives to signal their private information.

We continue with the consideration of income-smoothing incentives. Higher variability in earnings reflects greater cash flow risk, leading to a higher risk premium required by shareholders. In addition, banks that experience noisier earnings are more likely to exhibit greater information asymmetry between managers and outside investors. In their survey, Dichev et al. (2013) highlight that the high deviation from industry norms is also the second most frequent "red flag" that leads to incentives to manipulate accounting numbers. Graham, Harvey, and Rajgopal (2005) document that $96.9 \%$ of CFOs prefer a smooth earnings path. Thus, banks with high variability in earnings have more incentives to manage their financial reports. Under strong pressure from capital markets, public banks with large deviations in earnings should be more likely than private banks to use LLPs as a device to reduce their noisy earnings and comply with investor expectations. We should expect banks which have very low (high) current earnings to manage future DLLPs upward (downward).

Next, we test whether capital requirements have different effects on the earnings management incentives of public versus private banks. Prior studies suggest potential manipulation of accounting information due to capital requirements. Banks with low capital are more likely to manipulate their financial reports when the threat of regulatory intervention is high ( Beatty, Chamberlain, and Magliolo, 1995; Collins, Shackelford, and Wahlen, 1995). We therefore suspect the positive association between accounting manipulation and listing status is heightened for public banks, which are subject to a greater degree of regulatory scrutiny.

Following prior literature (e.g., Kim and Kross, 1998; Ahmed, Takeda, and Thomas, 1999; Kanagaretnam, Lobo, and Yang, 2004), we identify (i) banks with large changes in future cashflow as being more likely to signal their private information (signaling hypothesis), (ii) banks with high and low current premanaged earnings as being more likely to smooth future income (income-smoothing hypothesis), and (iii) banks with a low regulatory capital ratio to manage capital to a greater extent (capital management hypothesis). We construct a dummy variable,

\footnotetext{
${ }^{22}$ Increasing LLPs would lower managers' compensation due to earnings-related compensation. The literature also documents the use of dividends to convey private information.
} 
Dum_Signal, to indicate whether banks have high incentives to signal. Dum_Signal equals 1 if the change in future premanaged earnings $\left(\right.$ debllp $\left._{t+1}\right)$ is in the top quartile of the sample, and 0 otherwise. The dummy variable Dum_Smooth (we use multiple smoothing dummy variables) indicates banks that have high incentives to smooth their income. Banks with low earnings have greater incentives to manipulate earnings upward whereas banks with high earnings have incentives for income-decreasing manipulation. Thus, we create three different dummy variables: (i) Dum_Smooth-1 equals one if deviation of current earnings from the average of the industry is in the top fourth (highest) quartile of the sample, and zero otherwise.; (ii) Dum_Smooth_2 equals to 1 if bank's earnings are belong to top fourth quartile of earnings and volatility of earnings.; (iii) Dum_Smooth_3 equals one if bank earnings are in the bottom quartile of earnings and the top fourth quartile of earnings volatility. We expect the coefficients on all of our unsigned smoothing variables to be positive, while the coefficients on the interaction Listing*Dum_Smooth to be positive. A positive coefficient on Dum_Smooth indicates the firm has increased the magnitude of DLLPs.

Finally, we construct the dummy variable Dum_Capital to identify banks with strong incentive manage capital through LLPs. Dum_Capital equals one for banks which have low Tier 1 capital (in the bottom quartile) and loan-loss allowances of less than $1.25 \%$ of risk-weighted assets, and zero otherwise. We use these restrictions because loan-loss allowance is not included in Tier 1 capital, and only included in Tier 2 capital to $1.25 \%$ of risk-weighted assets under the new capital regulation regime. ${ }^{23}$ The Dum_Capital variable allows us to identify banks with a greater likelihood of regulatory intervention. We modify Equation (2) by including separately these dummy variables and their interaction effects with listing status to test our hypotheses. We report our results in Table 10.

\subsection{Tests of the signaling hypothesis}

In Models (1)-(3) of Panel A in Table 10 we regress both signed and unsigned DLLPs on Listing, Dum_Signal, and the interaction (Listing*Dum_Signal), as well as control variables, bank-level

\footnotetext{
${ }^{23}$ Under the old regime of capital regulation (pre-Basel), a one-dollar increase in LLPs would decrease earnings and consequently primary capital by the dollar amount of (1-tax rate), but would increase primary capital by one dollar provision since the loan-loss allowance is included in regulatory capital. Under the new regime of capital regulation (post-Basel), Tier 1 capital does not contain loan-loss allowance, but Tier 2 capital does unless loan-loss allowance is less than $1.25 \%$ of risk-weighted assets. In that situation, a one-dollar increase in LLPs increases total capital by the dollar amount of the tax rate. In contrast, when loan-loss allowance is higher than $1.25 \%$ of risk-weighted assets, the increase in LLPs entails a decrease in total capital by the dollar amount of (1-tax rate).
} 
fixed effects, and time fixed effects. We find public banks with greater incentive to signal their private information are more likely to manipulate their accounts than private banks with high signaling incentives, as indicated by a positive and significant coefficient of interaction Listing*Dum_Signal (Model (1)). The estimations with signed DLLPs tell us more about the relationship. Specifically, public banks with greater incentives to signal are more likely to increase PDLLPs (Model (3)), and decrease (absolute) NDLLPs (Model (2)). However, the coefficient on the interaction of Listing*Dum_Signal in Model (2) is not significant. In other words, public banks with greater incentives to signal tend to use income-decreasing DLLPs to signal their financial strength, which is consistent with our signaling hypothesis. ${ }^{24}$

\subsection{Tests of the capital management hypothesis}

We investigate the effect of capital management incentives on DLLPs in Models (4)-(6) of Panel A of Table 10. In Model (4) we regress DLLPs on Listing, Dum_Reg, Listing*Dum_Reg, control variables, and fixed effects. The negative coefficient on Dum_Reg indicates banks which are most likely to face regulatory scrutiny engage in less management of LLPs, which runs counter to our expectation. The positive coefficient on the interaction term (Listing*Dum_Reg) indicates publicly traded banks, which are most likely to face regulatory scrutiny, have greater incentive to increase LLPs in the future than other banks, consistent with the capital management hypothesis. In Model (5), the positive interaction term coefficient indicates that public banks with high probabilities of regulatory intervention are more likely to increase their (absolute) NDLLPs, resulting in higher earnings and higher capital. This finding does confirm our capital management hypothesis. Similarly, in Model (6), the negative interaction term coefficient suggests that public banks with high probabilities of regulatory intervention are more likely to decrease their PDLLPs. However, the coefficient is not significant.

\subsection{Tests of the income-smoothing hypothesis}

In Panel B of Table 10 we report our results of the tests of the impact of high earnings on the DLLPs of public and private banks. We regress both signed and unsigned DLLPS on Listing, our measures of earnings smoothing Listing*Dum_Smooth, controls and fixed effects. The positive

\footnotetext{
${ }^{24}$ Liu, Ryan, and Wahlen (1997) show that signaling findings hold for the $4^{\text {th }}$ quarter. We rerun our analysis with only $4^{\text {th }}$ quarter data, and find similar results.
} 
coefficient on Listing*Dum_Smooth_1 in Model (1) indicates public firms with high current earnings increase DLLPs to a greater extent than private firms with high industry-adjusted earnngs over the next quarter. In short, this finding suggests that public banks with high earnings are more likely to manipulate their earnings. The estimations with signed DLLPs tell us more about this relationship. Specifically, in Model (2), we find a negative relationship between the Dum_Smooth_1 and NDLLP, indicating firms which have high earnings in year $t$ and engage in negative earnings manipulation manipulate earnings lower than other banks which do not have earnings in the top quartile of the industry during during quarter $t$. The coefficient on the interaction term is positive, indicating that public banks with poor current earnings tend to manage DLLPs downward to a lesser extent than do comparable private banks. This could be due to less information asymmetry between management and investors. In Model (3) our positive coefficient on Dum_Smooth_1 indicates banks with high earnings manage DLLPs upward to a greater extent than banks with poorer earnings over the same quarter.

In Models (4)-(6), we regress signed and unsigned DLLPs on Listing, Dum_Smooth_2, Listing*Dum_Smooth_2, control variables and fixed effects. Dum_Smooth_2 equals one if both the historical earnings volatility and quarterly earnings are in the top quartile during the quarter. We find positive coefficients on Dum_Smooth_2 in all three models, indicating that banks with volatile and high earnings exhibit more positive DLLPs than their counterparts regardless of whether those DLLPs are positive or negative. This finding is consistent with the fact that managers have the incentive to at least meet or beat earnings expectations, signal to investors the superior performance of the firm, or simply convince investors of the viability of the bank, which could improve the value of managers' option-based compensation. The positive and significant coefficient on the interaction term in Models (4) and (5) indicates that public banks engage in this activity to the greatest extent. This is consistent with the possibility that these individuals could benefit from their option- or stock-based compensation when investors bid the price of the bank's shares up.

In Models (7)-(9), we regress both signed and unsigned DLLPs on Listing, Dum_Smooth_3, Listing*Dum_Smooth_3, control variables and fixed effects. Dum_Smooth_2 equals one if both the historical earnings volatility is in the top quartile and quarterly earnings are in the bottom quartile during the quarter. Consistent with our findings in Models (4)-(6), we find a positive relationship between Dum_Smooth_3 and both signed and unsigned DLLPs. The 
positive and significant coefficient on the interaction between Listing and Dum_Smooth_3 indicates that publicly traded firms with high earnings volatility but poor current earnings manage their DLLPs to a greater magnitude than private banks with similarly volatile earnings.

Our results in Panel B suggest minimal evidence for the earnings smoothing hypothesis. Banks with high earnings volatility do appear to manage their DLLPs to a greater extent, but they do not appear to consistently manage DLLPs in a manner consistent with the income-smoothing hypothesis. Public banks appear to manage earnings to a greater extent than private banks. There are several possible explanations for these findings. On the one hand, when banks experience lower earnings than industry average, they may miss the expectations of investors (this is especially true of public banks). Koh, Matsumoto, and Rajgopal (2008) document that the penalty to big misses is not larger than the penalty to small misses, suggesting that markets could equally penalize firms for both large and small misses. And this miss of expectations could induce opportunistic behavior in managers to increase LLPs to form "cookie jar" reserves for future periods. On the other hand, when banks' earnings are higher than industry's average, banks' managers would report what the market wants to "hear" (Jensen, 2005). Koh, Matsumoto, and Rajgopal (2008) show that abnormal returns would be much higher when firms largely beat the expectations. Thus, we suggest that public banks with high earnings in our sample use income-increasing manipulation to boost the earnings higher, and then experience higher stock returns. In brief, our findings in Table 10 suggest public banks are more likely to use DLLPs to either signal future earnings or manage capital than to smooth income.

\section{Conclusions}

While most prior studies of earnings management relate to public banks or non-bank entities, we provide one of the first large-sample comparisons of earnings management (through DLLPs) in public and private US banks. Our study provides details of the differences in managerial discretion of public and private banks. We exploit a dataset which allows us to examine the impact of variations in information asymmetry. Our finding suggests that public banks are more likely to manage their accounts through $D L L P$ s than private banks. This finding is robust to various robustness tests. Our evidence is consistent with those of prior banking studies by Beatty and Harris (1999), Beatty, Ke, and Petroni (2002), and prior studies of non-financial firms (Givoly, Hayn, and Katz (2010)). 
We also examine the incentives for managing $D L L P$ s by banks with high incentives to signal their private information, smooth income, and manage capital to comply with capital requirements. Our analysis of the incentives indicates DLLPS of public banks are increased by banks with greater incentives to signal, which confirms the signaling hypothesis. We do not find evidence consistent with our income-smoothing hypothesis, since public banks with low earnings are more likely to use income-decreasing earnings management whereas public banks with high earnings are more likely to use income-increasing earnings management. Finally, we examine whether banks which are more likely to face regulatory scrutiny manage $D L L P$ s to a greater extent. We find evidence to support this hypothesis.

Taken together, our results indicate bank ownership alters the use of discretionary loanloss provisions by management. This finding leads to several follow-up questions. Does bank ownership effect other discretionary decisions by management such as merger or divestiture activity? Do blockholdings of by institutional investors have a linear effect on the loan-loss provisions of banks? How accurate are the loan loss provisions of public and private banks? All of these are potential questions for future study. 


\section{References}

Ahmed, Anwer S., Carolyn Takeda, and Shawn Thomas, 1999, Bank loan loss provisions: a reexamination of capital management, earnings management and signaling effects, Journal of Accounting and Economics 28, 1-25.

Ball, Ray, and Lakshmanan Shivakumar, 2005, Earnings quality in UK private firms: comparative loss recognition timeliness, Journal of Accounting and Economics 39, 83-128.

Barton, Jan, and Gregory Waymire, 2004, Investor protection under unregulated financial reporting, Journal of Accounting and Economics 38, 65-116.

Bartov, Eli, Dan Givoly, and Carla Hayn, 2002, The rewards to meeting or beating earnings expectations, Journal of Accounting and Economics 33, 173-204.

Beatty, Anne, Sandra L. Chamberlain, and Joseph Magliolo, 1995, Managing Financial Reports of Commercial Banks: The Influence of Taxes, Regulatory Capital, and Earnings, Journal of Accounting Research 33, 231-261.

Beatty, Anne, and David G. Harris, 1999, The Effects of Taxes, Agency Costs and Information Asymmetry on Earnings Management: A Comparison of Public and Private Firms, Review of Accounting Studies 4, 299-326.

Beatty, Anne L., Bin Ke, and Kathy R. Petroni, 2002, Earnings Management to Avoid Earnings Declines across Publicly and Privately Held Banks, Accounting Review 77, 547-570.

Beatty, Anne, and Scott Liao, 2014, Financial accounting in the banking industry: A review of the empirical literature, Journal of Accounting \& Economics 58, 339-383.

Beaver, William, Carol Eger, Stephen Ryan, and Mark Wolfson, 1989, Financial Reporting, Supplemental Disclosures, and Bank Share Prices, Journal of Accounting Research 27, 157-178.

Beaver, William H., and Ellen E. Engel, 1996, Discretionary behavior with respect to allowances for loan losses and the behavior of security prices, Journal of Accounting and Economics 22, $177-206$.

Bebchuk, Lucian, Alma Cohen, and Allen Ferrell, 2009, What Matters in Corporate Governance?, Review of Financial Studies 22, 783-827.

Beck, Paul J., and Ganapathi S. Narayanamoorthy, 2013, Did the SEC impact banks' loan loss reserve policies and their informativeness?, Journal of Accounting and Economics 56. Conference Issue on Accounting Research on Classic and Contemporary IssuesUniversity of Rochester, Simon Business School, 42-65.

Berger, Allen N., and Christa H. S. Bouwman, 2013, How does capital affect bank performance during financial crises?, Journal of Financial Economics 109, 146-176. 
Bergstresser, Daniel, and Thomas Philippon, 2006, CEO incentives and earnings management, Journal of financial economics 80, 511-529.

Black, Bernard S., 1992, Institutional investors and corporate governance: The case for institutional voice, Journal of applied corporate finance 5, 19-32.

Bowen, Robert M., Eric W. Noreen, and John M. Lacey, 1981, Determinants of the corporate decision to capitalize interest, Journal of Accounting and Economics 3, 151-179.

Brown, Jeffrey R., Zoran Ivković, Paul A. Smith, and Scott Weisbenner, 2008, Neighbors Matter: Causal Community Effects and Stock Market Participation, The Journal of Finance 63, 1509-1531.

Burgstahler, David C., Luzi Hail, and Christian Leuz, 2006, The Importance of Reporting Incentives: Earnings Management in European Private and Public Firms, The Accounting Review 81, 983-1016.

Burgstahler, David, and Ilia Dichev, 1997, Earnings management to avoid earnings decreases and losses, Journal of Accounting and Economics 24. Properties of Accounting Earnings, 99126.

Bushee, Brian J., 1998, The influence of institutional investors on myopic R\&D investment behavior, Accounting review, 305-333.

Bushman, Robert M., and Christopher D. Williams, 2012, Accounting discretion, loan loss provisioning, and discipline of Banks' risk-taking, Journal of Accounting and Economics 54, 118.

Christie, Andrew A., and Jerold L. Zimmerman, 1994, Efficient and opportunistic choices of accounting procedures: Corporate control contests, Accounting Review, 539-566.

Collins, Julie H., Douglas A. Shackelford, and James M. Wahlen, 1995, Bank Differences in the Coordination of Regulatory Capital, Earnings, and Taxes, Journal of Accounting Research 33, 263-291.

DeAngelo, Linda Elizabeth, 1988, Managerial competition, information costs, and corporate governance, Journal of Accounting and Economics 10, 3-36.

Dechow, Patricia M., Richard G. Sloan, and Amy P. Sweeney, 1995, Detecting earnings management, Accounting review, 193-225.

Dechow, Patricia M., and Ilia D. Dichev, 2002, The Quality of Accruals and Earnings: The Role of Accrual Estimation Errors, The Accounting Review 77, 35-59.

Dechow, Patricia, Weili Ge, and Catherine Schrand, 2010, Understanding earnings quality: A review of the proxies, their determinants and their consequences, Journal of Accounting and Economics 50, 344-401. 
DeFond, Mark L., and James Jiambalvo, 1994, Debt covenant violation and manipulation of accruals, Journal of Accounting and Economics 17, 145-176.

Degeorge, Fran \&, Jayendu Patel, and Richard Zeckhauser, 1999, Earnings Management to Exceed Thresholds, Journal of Business 72, 1-33.

Dichev, Ilia D., John R. Graham, Campbell R. Harvey, and Shiva Rajgopal, 2013, Earnings quality: Evidence from the field, Journal of Accounting and Economics 56. Conference Issue on Accounting Research on Classic and Contemporary IssuesUniversity of Rochester, Simon Business School, 1-33.

Doyle, Jeffrey T., Weili Ge, and Sarah McVay, 2007, Accruals Quality and Internal Control over Financial Reporting, The Accounting Review 82, 1141-1170.

Fama, Eugene F., and Michael C. Jensen, 1983, Agency Problems and Residual Claims, Journal of Law and Economics 26, 327-349.

Ferreira, Daniel, Gustavo Manso, and André C. Silva, 2014, Incentives to Innovate and the Decision to Go Public or Private, Review of Financial Studies 27, 256-300.

Francis, Jennifer, Per Olsson, and Katherine Schipper, 2006, Earnings Quality, Foundations and Trends ${ }^{\circledR}$ in Accounting 1, 259-340.

Frankel, Richard M., Marilyn F. Johnson, and Karen K. Nelson, 2002, The Relation between Auditors' Fees for Nonaudit Services and Earnings Management, Accounting Review 77, 71.

Gao, Huasheng, Jarrad Harford, and Kai Li, 2015, CEO turnover-performance sensitivities in private firms, Journal of Financial and Quantitative Analysis (JFQA), Forthcoming.

Givoly, Dan, Carla K. Hayn, and Sharon P. Katz, 2010, Does Public Ownership of Equity Improve Earnings Quality?, Accounting Review 85, 195-225.

Graham, John R., Campbell R. Harvey, and Shiva Rajgopal, 2005, The economic implications of corporate financial reporting, Journal of Accounting and Economics 40, 3-73.

Healy, Paul M., 1985, The effect of bonus schemes on accounting decisions, Journal of Accounting and Economics 7, 85-107.

Healy, Paul M., and James M. Wahlen, 1999, A Review of the Earnings Management Literature and Its Implications for Standard Setting, Accounting Horizons 13, 365-383.

Heckman, James J., Hidehiko Ichimura, and Petra E. Todd, 1997, Matching as an econometric evaluation estimator: Evidence from evaluating a job training programme, The review of economic studies 64, 605-654.

Hope, Ole-Kristian, Wayne B. Thomas, and Dushyantkumar Vyas, 2013, Financial Reporting Quality of U.S. Private and Public Firms, The Accounting Review 88, 1715-1742. 
Jensen, Michael C., 2005, Agency Costs of Overvalued Equity, Financial Management 34, 5-19.

Jiang, Liangliang, Ross Levine, and Chen Lin, 2016, Competition and bank opacity, Review of Financial Studies 29, 1911-1942.

Jones, Jennifer J., 1991, Earnings management during import relief investigations, Journal of accounting research, 193-228.

Kai, Li, and Nagpurnanand R. Prabhala, 2007, Chapter 2 - Self-Selection Models in Corporate Finance* A2 - Eckbo, B. Espen, Handbook of Empirical Corporate Finance. Handbooks in Finance (Elsevier, San Diego).

Kanagaretnam, Kiridaran, Gopal V. Krishnan, and Gerald J. Lobo, 2010, An Empirical Analysis of Auditor Independence in the Banking Industry, The Accounting Review 85, 2011-2046.

Kanagaretnam, Kiridaran, Gerald J. Lobo, and DONG-HOON Yang, 2004, Joint tests of signaling and income smoothing through bank loan loss provisions, Contemporary Accounting Research 21, 843-884.

Kim, Jeong-Bon, and Cheong H. Yi, 2006, Ownership Structure, Business Group Affiliation, Listing Status, and Earnings Management: Evidence from Korea*, Contemporary Accounting Research 23, 427-464.

Kim, Myung-Sun, and William Kross, 1998, The impact of the 1989 change in bank capital standards on loan loss provisions and loan write-offs, Journal of Accounting and Economics 25, 69-99.

Koh, Kevin, Dawn A. Matsumoto, and Shivaram Rajgopal, 2008, Meeting or Beating Analyst Expectations in the Post-Scandals World: Changes in Stock Market Rewards and Managerial Actions*, Contemporary Accounting Research 25, 1067-1098.

Kothari, S. P., Andrew J. Leone, and Charles E. Wasley, 2005, Performance matched discretionary accrual measures, Journal of Accounting and Economics 39, 163-197.

Leuz, Christian, Dhananjay Nanda, and Peter D Wysocki, 2003, Earnings management and investor protection: an international comparison, Journal of Financial Economics 69, 505-527.

Levitt, A., 1998, The numbers game. Speech delivered at New York University, Center for Law and Business, September 28.

Liu, Chi-Chun, and Stephen G. Ryan, 1995, The effect of bank loan portfolio composition on the market reaction to and anticipation of loan loss provisions, Journal of Accounting Research, 7794.

Liu, Chi-Chun, Stephen G. Ryan, and James M. Wahlen, 1997, Differential valuation implications of loan loss provisions across banks and fiscal quarters, Accounting Review, 133146. 
Nichols, D. Craig, James M. Wahlen, and Matthew M. Wieland, 2009, Publicly traded versus privately held: implications for conditional conservatism in bank accounting, Review of Accounting Studies 14, 88-122.

Penman, Stephen H., Scott A. Richardson, and Irem Tuna, 2007, The Book-to-Price Effect in Stock Returns: Accounting for Leverage, Journal of Accounting Research 45, 427-467.

Penno, Mark, and Daniel T. Simon, 1986, Accounting Choices: Public Versus Private Firms, Journal of Business Finance \& Accounting 13, 561-569.

Rosenbaum, Paul R., and Donald B. Rubin, 1983, The central role of the propensity score in observational studies for causal effects, Biometrika 70, 41-55.

Scholes, Myron S., G. Peter Wilson, and Mark A. Wolfson, 1990, Tax planning, regulatory capital planning, and financial reporting strategy for commercial banks, Review of financial Studies 3, 625-650.

Skinner, Douglas J., and Richard G. Sloan, 2002, Earnings Surprises, Growth Expectations, and Stock Returns or Don't Let an Earnings Torpedo Sink Your Portfolio, Review of Accounting Studies 7, 289-312.

Smith, E. Daniel, 1976, The Effect of the Separation of Ownership from Control on Accounting Policy Decisions, The Accounting Review 51, 707-723.

Teoh, Siew Hong, Ivo Welch, and T. J. Wong, 1998, Earnings Management and the Long-Run Market Performance of Initial Public Offerings, The Journal of Finance 53, 1935-1974.

Teoh, Siew Hong, Ivo Welch, and Tak Jun Wong, 1998, Earnings management and the underperformance of seasoned equity offerings, Journal of Financial economics 50, 63-99.

Wahlen, James M., 1994, The nature of information in commercial bank loan loss disclosures, Accounting Review, 455-478.

Warfield, Terry D., John J. Wild, and Kenneth L. Wild, 1995, Managerial ownership, accounting choices, and informativeness of earnings, Journal of accounting and economics 20, 61-91.

Watts, Ross L., and Jerold L. Zimmerman, 1986, Positive accounting theory, . 


\section{Table 1. Variables Definitions}

This table presents definitions of all variables used in the analysis.

\begin{tabular}{|c|c|}
\hline Variable & Definition \\
\hline DLLPs & $\begin{array}{l}\text { Logarithm of absolute value of residual from: } \\
\begin{array}{l}l l p_{i t}=d n p l_{i t+1}+d n p l_{i t}+d n p l_{i t-1}+d n p l_{i t-2}+a l w_{i t-1}+\text { cho }_{i t}+\text { size }_{i t}+\text { dloan }_{i t} \\
\quad+\text { csret }_{i t}+d g d p_{i t}+\text { dunemp }_{i t}+\epsilon_{i t}\end{array}\end{array}$ \\
\hline NDLLPS & $\begin{array}{l}\text { Logarithm of absolute value of negative residual from: } \\
\begin{array}{l}l l p_{i t}=d n p l_{i t+1}+d n p l_{i t}+d n p l_{i t-1}+d n p l_{i t-2}+a l w_{i t-1}+\text { cho }_{i t}+\text { size }_{i t}+\text { dloan }_{i t} \\
+ \text { csret }_{i t}+d g d p_{i t}+d u n e m p_{i t}+\epsilon_{i t}\end{array}\end{array}$ \\
\hline PDLLPS & $\begin{array}{l}\text { Logarithm of absolute value of positive residual from: } \\
\begin{aligned} l l p_{i t}=d n p l_{i t+1}+d n p l_{i t}+d n p l_{i t-1}+d n p l_{i t-2}+a l w_{i t-1}+\text { cho }_{i t}+\text { size }_{i t}+\text { dloan }_{i t} \\
\quad+\text { csret }_{i t}+d g d p_{i t}+\text { dunemp }_{i t}+\epsilon_{i t}\end{aligned}\end{array}$ \\
\hline DLLPs_1 & $\begin{array}{l}\text { Logarithm of absolute value of residual from: } \\
\begin{array}{l}\operatorname{llp}_{i t}=d n p l_{i t+1}+d n p l_{i t}+d n p l_{i t-1}+d n p l_{i t-2}+\text { size }_{i t}+\text { dloan }_{i t}+\text { csret }_{i t}+d g d p_{i t} \\
+d u n e m p_{i t}+\epsilon_{i t}\end{array}\end{array}$ \\
\hline DLLPS_2 & $\begin{array}{l}\text { Logarithm of absolute value of residual from: } \\
\begin{array}{l}l l p_{i t}=d n p l_{i t+1}+d n p l_{i t}+d n p l_{i t-1}+d n p l_{i t-2}+\operatorname{size}_{i t}+d l o a n_{i t}+a l w_{i t-1}+\text { csret }_{i t} \\
\quad+d g d p_{i t}+d u n e m p_{i t}+\epsilon_{i t}\end{array}\end{array}$ \\
\hline DLLPS_3 & $\begin{array}{l}\text { Logarithm of absolute value of residual from: } \\
\begin{aligned} l l p_{i t}=d n p l_{i t+1}+d n p l_{i t}+d n p l_{i t-1}+d n p l_{i t-2}+\text { size }_{i t}+d \text { loan }_{i t}+\text { cho }_{i t}+\text { csret }_{i t} \\
+d g d p_{i t}+d u n e m p_{i t}+\epsilon_{i t}\end{aligned}\end{array}$ \\
\hline$\overline{D R S G L}$ & $\begin{array}{l}\text { Logarithm of absolute value of residual from: } \\
r s g l_{i t}=\operatorname{size}_{i t}+u r s g l_{i t}+\varepsilon_{i t}\end{array}$ \\
\hline DEARN & DRSGL-DLLPS \\
\hline
\end{tabular}


Table 1 (continued)

\begin{tabular}{|c|c|}
\hline \multicolumn{2}{|l|}{ Components of DLLPs models } \\
\hline NPL & $\begin{array}{l}\text { Nonperforming assets over the quarter, scaled by total loans at the beginning of } \\
\text { the quarter }\end{array}$ \\
\hline DNPL & $\begin{array}{l}\text { Change in NPA over the quarter, divided by total loans at the beginning of the } \\
\text { quarter }\end{array}$ \\
\hline$L O A N$ & Total loans over the quarter \\
\hline$D L O A N$ & $\begin{array}{l}\text { Change in total loans over the quarter, divided by total loans at the beginning of } \\
\text { the quarter }\end{array}$ \\
\hline$A L W$ & Loan loss allowance as a percentage of lagged total loans \\
\hline $\mathrm{CHO}$ & Adjusted charge-off as a percentage of lagged total loans \\
\hline$R S G L$ & $\begin{array}{l}\text { Realized security gains and losses as a percentage of total assets (includes } \\
\text { realized gains and losses from available-for sale securities and held-to-maturity } \\
\text { securities) }\end{array}$ \\
\hline URSGL & $\begin{array}{l}\text { Unrealized security gains and losses (includes only unrealized gains and losses } \\
\text { from available-for-sale securities) as a percentage of total assets; }\end{array}$ \\
\hline SIZE & The natural logarithm of gross total assets \\
\hline CSRET & The return on the Case-Shiller Real Estate Index over the quarter \\
\hline DUNEMP & Change in unemployment rates over the quarter \\
\hline DGDP & Change in GSP (gross state product) over the quarter \\
\hline \multicolumn{2}{|l|}{ Variable of interest } \\
\hline LISTING & $\begin{array}{l}\text { A dummy that takes a value of } 1 \text { if the bank is listed on a stock exchange or is } \\
\text { part of a bank holding company that is listed on a stock exchange and } 0 \\
\text { otherwise. }\end{array}$ \\
\hline \multicolumn{2}{|r|}{ ( } \\
\hline CAPITAL & Book value of equity over gross total assets \\
\hline$T 1 R$ & Tier 1 capital over risk-weighted-assets \\
\hline DUMMY LOSS & A dummy variable that equals one if net income is negative, and zero otherwise \\
\hline PREMANAGED EARNINGS & Income before taxes, provisions recognized in income over gross total assets \\
\hline FED & $\begin{array}{l}\text { A dummy equal to } 1 \text { if the bank is a state-chartered Federal Reserve System } \\
\text { member, } 0 \text { otherwise }\end{array}$ \\
\hline OCC & A dummy equal to 1 if the bank has a national bank charter, and 0 otherwise. \\
\hline FI_CRISES & $\begin{array}{l}\text { A dummy equal to } 1 \text { for a financial crisis period, and } 0 \text { otherwise., following } \\
\text { Berger and Bouwman (2013) }\end{array}$ \\
\hline BK_CRISES & $\begin{array}{l}\text { A dummy equal to } 1 \text { for a banking crisis period, and } 0 \text { otherwise., following } \\
\text { Berger and Bouwman (2013) }\end{array}$ \\
\hline MK_CRISES & $\begin{array}{l}\text { A dummy equal to } 1 \text { for a market crisis period, and } 0 \text { otherwise., following } \\
\text { Berger and Bouwman (2013) }\end{array}$ \\
\hline DUM_SIGNAL & $\begin{array}{l}\text { A dummy equal to } 1 \text { if the change in one-year-ahead future premanaged earnings } \\
\left(\text { debllp }_{t+1}\right) \text { is in the top fourth (highest) quartile of the sample, and } 0 \text { otherwise. }\end{array}$ \\
\hline DUM_SMOOTH_1 & $\begin{array}{l}\text { A dummy equal to } 1 \text { if earnings are in the top quartile during the quarter and } \\
\text { equal to } 0 \text { otherwise. }\end{array}$ \\
\hline DUM_SMOOTH_2 & $\begin{array}{l}\text { A dummy equal to } 1 \text { if the bank's earnings are in the top quartile of earnings and } \\
\text { top quartile of earnings volatility and equal to } 0 \text { otherwise. }\end{array}$ \\
\hline Dum_Smooth_3 & $\begin{array}{l}\text { A dummy equal to } 1 \text { if the bank's earnings are in the bottom quartile of earnings } \\
\text { and top quartile of earnings volatility and equal to } 0 \text { otherwise. }\end{array}$ \\
\hline DUM_CAPITAL & $\begin{array}{l}\text { A dummy equal to } 1 \text { if banks have low Tier } 1 \text { capital (in the bottom quartile) and } \\
\text { have loan loss allowance less than } 1.25 \text { percent of risk-weighted assets. }\end{array}$ \\
\hline BFE & Bank fixed effects, represented by dummies for each commercial bank. \\
\hline TFE & $\begin{array}{l}\text { Time fixed effects, represented by dummies for each quarter of the sample } \\
\text { period. }\end{array}$ \\
\hline
\end{tabular}


Table 2. Summary Statistics for the Main Sample

This table reports summary statistics for the main sample of U.S. commercial banks used in the analysis. The sample period is from 1986:Q1 to 2013:Q4. All financial variables are winsorized at 1\% and 99\% levels. Panel A, B, and C show the summary statistics for private banks, public banks, and the full sample, respectively.

\section{Panel A: Private Banks}

\begin{tabular}{lllllllll}
\hline Variables & $\mathrm{N}$ & Mean & St. Dev & Skewness & Kurtosis & P25 & P50 & P75 \\
\hline Size & 713036 & 11.449 & 0.937 & 1.164 & 5.091 & 10.739 & 11.291 & 11.964 \\
Capital ratio & 713036 & 0.098 & 0.032 & 1.473 & 6.080 & 0.078 & 0.092 & 0.111 \\
Tier 1 ratio & 431676 & 0.160 & 0.074 & 2.169 & 8.811 & 0.113 & 0.138 & 0.182 \\
Dummy loss & 712243 & 0.096 & 0.294 & 2.749 & 8.559 & 0.000 & 0.000 & 0.000 \\
Premanaged earnings & 712242 & 0.016 & 0.010 & -0.474 & 6.352 & 0.011 & 0.016 & 0.021 \\
Fed & 713036 & 0.382 & 0.486 & 0.484 & 1.234 & 0.000 & 0.000 & 1.000 \\
OCC & 713036 & 0.279 & 0.449 & 0.985 & 1.970 & 0.000 & 0.000 & 1.000 \\
\hline
\end{tabular}

Panel B: Public Banks

\begin{tabular}{lllllllll}
\hline Variables & $\mathrm{N}$ & Mean & St. Dev & Skewness & Kurtosis & P25 & P50 & P75 \\
\hline Size & 133901 & 12.738 & 1.521 & 0.542 & 2.473 & 11.566 & 12.489 & 13.711 \\
Capital ratio & 133901 & 0.087 & 0.030 & 2.073 & 9.036 & 0.069 & 0.081 & 0.096 \\
Tier 1 ratio & 62159 & 0.127 & 0.054 & 3.788 & 22.999 & 0.098 & 0.113 & 0.139 \\
Dummy loss & 133867 & 0.090 & 0.286 & 2.868 & 9.225 & 0.000 & 0.000 & 0.000 \\
Premanaged earnings & 133867 & 0.018 & 0.011 & -0.408 & 6.264 & 0.013 & 0.018 & 0.023 \\
Fed & 133901 & 0.566 & 0.496 & -0.268 & 1.072 & 0.000 & 1.000 & 1.000 \\
OCC & 133901 & 0.413 & 0.492 & 0.352 & 1.124 & 0.000 & 0.000 & 1.000 \\
\hline
\end{tabular}

\begin{tabular}{|c|c|c|c|c|c|c|c|c|}
\hline Variables & $\mathrm{N}$ & Mean & St. Dev & Skewness & Kurtosis & $\mathrm{P} 25$ & P50 & P75 \\
\hline Size & 846937 & 11.653 & 1.151 & 1.337 & 5.138 & 10.810 & 11.418 & 12.204 \\
\hline Capital ratio & 846937 & 0.097 & 0.032 & 1.528 & 6.301 & 0.076 & 0.090 & 0.109 \\
\hline Tier 1 ratio & 493835 & 0.156 & 0.072 & 2.268 & 9.425 & 0.110 & 0.135 & 0.176 \\
\hline Dummy loss & 846110 & 0.095 & 0.293 & 2.767 & 8.659 & 0.000 & 0.000 & 0.000 \\
\hline Premanaged earnings & 846109 & 0.016 & 0.010 & -0.438 & 6.314 & 0.011 & 0.016 & 0.021 \\
\hline Fed & 846937 & 0.412 & 0.492 & 0.360 & 1.129 & 0.000 & 0.000 & 1.000 \\
\hline OCC & 846937 & 0.300 & 0.458 & 0.871 & 1.759 & 0.000 & 0.000 & 1.000 \\
\hline
\end{tabular}




\section{Table 3. Baseline Multivariate Analysis}

This table reports regression estimates of the relation between earnings management and listing status. The dependent variables are DLLPs, NDLLPs and PDLLPs. The sample period is from 1986:Q1 to 2013:Q4. The main independent variable is Listing status. Models (1), (4), (7) are our baseline models, controls for size, capital ratio, dummy loss, premanaged earnings and regulatory (Fed and OCC) winsorized at he $1 \%$ and $99 \%$ levels.***,**** indicate significe

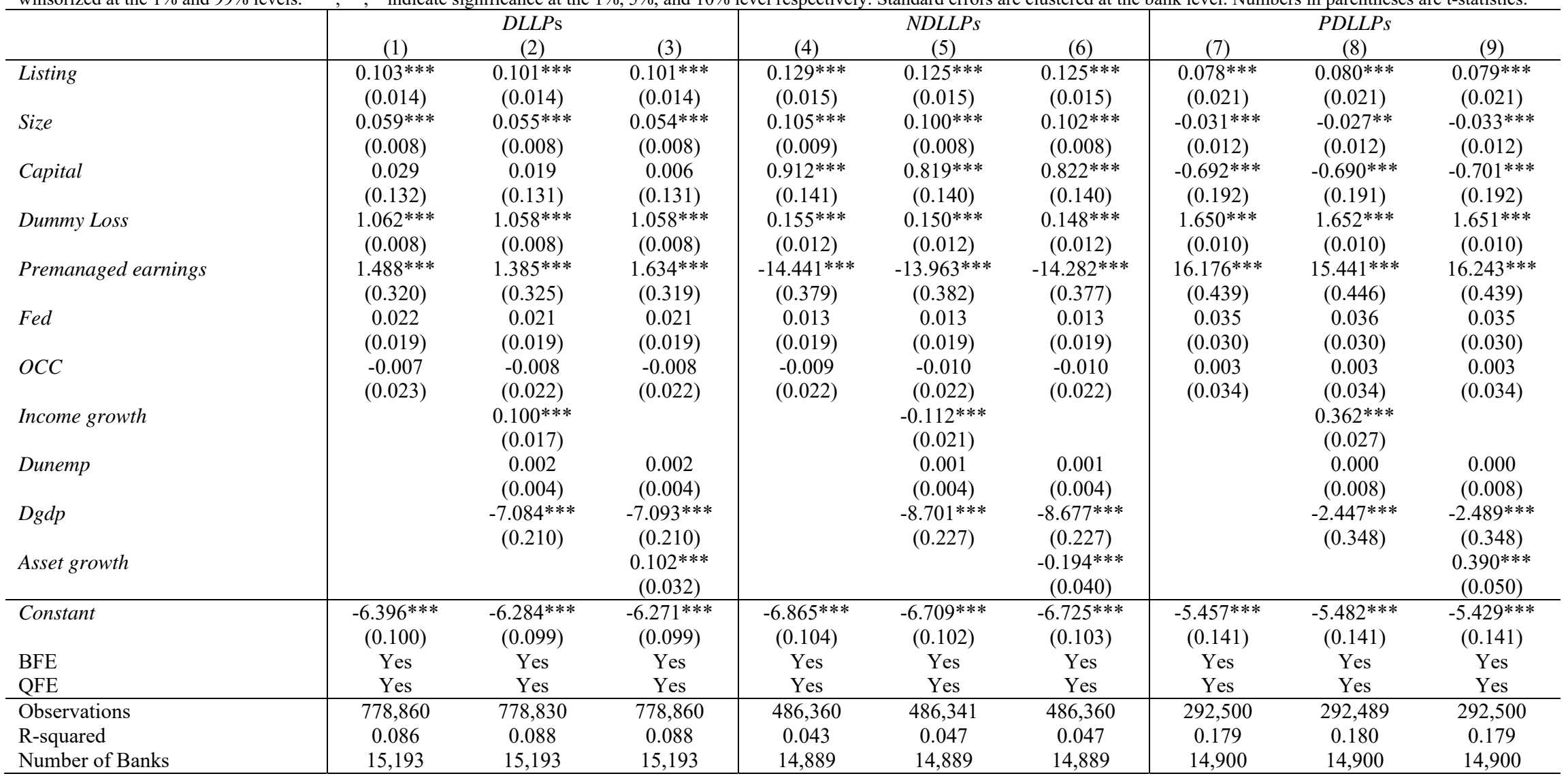


Table 4. Baseline Multivariate Analysis with Alternative Samples

This table reports regression estimates of the relation between earnings management and listing status. The dependent variables are DLLPs, NDLLPs and PDLLPs and the sample period is from 1986:Q1 to 2013:Q4. The main independent variable is Listing status. Models (1)-(3) use balance data, Models (4)-(6) use bank-holding level data. Models (7)-(9) use annual data. All regressions include bank and time (quarter) fixed effects. All financial variables are winsorized at the $1 \%$ and $99 \%$ levels. ***,**,* indicate significance at the $1 \%, 5 \%$, and $10 \%$ level respectively. Standard errors are clustered at the bank level (or BHC level). Numbers in parentheses are t-statistics.

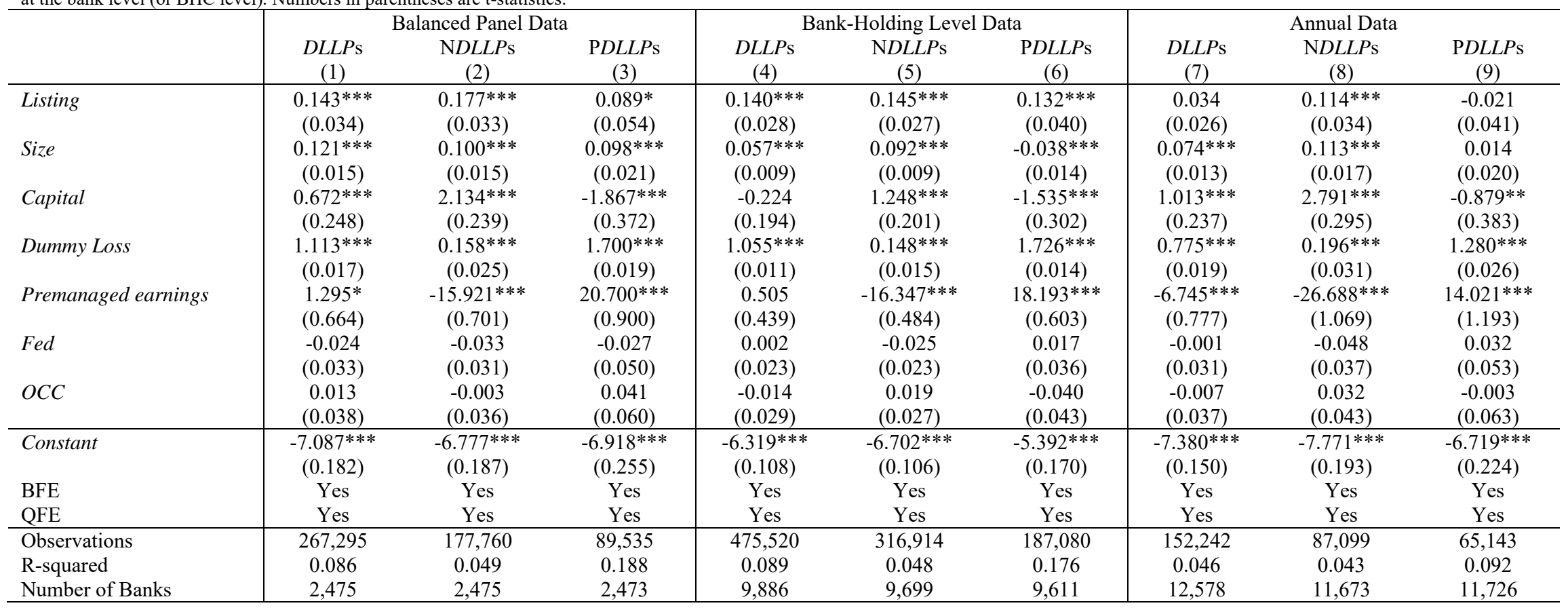


Table 5. Alternative Measures of Discretionary LLPs

This table reports regression estimates of the relation between earnings management and listing status. The sample period is from 1986:Q1 to 2013:Q4. The main independent variable is Listing. Models (1)-(5) report the results with different measures of DLLPs as defined in Table (1). All regressions include bank and time (quarter) fixed effects. All financial variables are winsorized at the 1\% and 99\% levels. $* * *, * * *$ indicate significance at the $1 \%, 5 \%$, and $10 \%$ level respectively. Standard errors are clustered at the bank level. Numbers in parentheses are t-statistics.

\begin{tabular}{|c|c|c|c|c|c|}
\hline & $\begin{array}{c}D L L P P_{-} 1 \\
\text { (1) }\end{array}$ & $\begin{array}{c}D L L P \mathrm{~s} \_2 \\
\text { (2) }\end{array}$ & $\begin{array}{c}D L L P \mathrm{~s} \_3 \\
\text { (3) }\end{array}$ & $\begin{array}{c}\text { DRSGL } \\
(4)\end{array}$ & $\begin{array}{c}\text { DEARN } \\
(5)\end{array}$ \\
\hline \multirow[t]{2}{*}{ Listing } & $0.083^{* * *}$ & $0.155 * * *$ & $0.114 * * *$ & $0.106^{* * *}$ & $0.215^{* * *}$ \\
\hline & $(0.013)$ & $(0.015)$ & $(0.014)$ & $(0.023)$ & $(0.021)$ \\
\hline \multirow[t]{2}{*}{ Size } & $0.159 * * *$ & $0.122 * * *$ & $0.050 * * *$ & $0.639 * * *$ & $0.722 * * *$ \\
\hline & $(0.007)$ & $(0.009)$ & $(0.008)$ & $(0.012)$ & $(0.012)$ \\
\hline \multirow[t]{2}{*}{ Capital } & 0.141 & $0.981 * * *$ & $0.291 * *$ & $2.232 * * *$ & $1.907 * * *$ \\
\hline & $(0.117)$ & $(0.138)$ & $(0.130)$ & $(0.179)$ & $(0.180)$ \\
\hline \multirow[t]{2}{*}{ Dummy Loss } & $1.302 * * *$ & $1.294 * * *$ & $1.078 * * *$ & $0.195 * * *$ & $0.577 * * *$ \\
\hline & $(0.009)$ & $(0.009)$ & $(0.008)$ & $(0.009)$ & $(0.009)$ \\
\hline \multirow[t]{2}{*}{ Premanaged earnings } & $8.047 * * *$ & $5.321 * * *$ & $1.486^{* * *}$ & 0.188 & $2.800 * * *$ \\
\hline & $(0.317)$ & $(0.342)$ & $(0.323)$ & $(0.370)$ & $(0.351)$ \\
\hline \multirow[t]{2}{*}{ Fed } & 0.017 & $0.037 *$ & 0.026 & -0.036 & 0.048 \\
\hline & $(0.017)$ & $(0.021)$ & $(0.020)$ & $(0.029)$ & $(0.030)$ \\
\hline \multirow[t]{2}{*}{ OCC } & 0.030 & 0.023 & -0.007 & $-0.089 * *$ & $-0.117 * * *$ \\
\hline & $(0.020)$ & $(0.025)$ & $(0.023)$ & $(0.035)$ & $(0.037)$ \\
\hline \multirow[t]{2}{*}{ Constant } & $-7.386 * * *$ & $-6.997 * * *$ & $-6.319 * * *$ & $-4.228 * * *$ & $-14.246^{* * *}$ \\
\hline & $(0.090)$ & $(0.106)$ & $(0.100)$ & $(0.147)$ & $(0.136)$ \\
\hline BFE & Yes & Yes & Yes & Yes & Yes \\
\hline QFE & Yes & Yes & Yes & Yes & Yes \\
\hline Observations & 778,860 & 778,860 & 778,860 & 560,060 & 805,003 \\
\hline R-squared & 0.126 & 0.119 & 0.088 & 0.117 & 0.922 \\
\hline Number of Banks & 15,193 & 15,193 & 15,193 & 12,431 & 15,373 \\
\hline
\end{tabular}




\section{Table 6. Matching Approaches}

This table reports regression estimates of the relation between earnings management and listing status. The dependent variables are DLLPs, NDLLPs and PDLLPs and the sample period is from 1986:Q1 to 2013:Q4. The main independent variable is Listing status. Model (1) reports results from one-to-one size-based matching, Models (2)-(3) reports results from PSM with N=1 with and without replacement, indicate significance at the $1 \%, 5 \%$, and $10 \%$ level respectively. Standard errors are clustered at the bank level. Numbers in parentheses are t-statistics. Size-based matching

\section{Listing}

Size

Capital

Dummy Loss

Premanaged earnings

Fed

OCC

$$
\text { Constant }
$$

BFE

QFE

\section{Observations}

R-squared

Number of Matches
(With replacement)

(1)

(2)

$0.147 * * *$
$(0.041)$

(0.027)

$0.077 * * *$

(0.024)

0.302

(0.351)

$1.107 * * *$

(0.022)

$2.591 * * *$

(0.703)

$0.093 * * *$

(0.036)

$-0.079 * *$

$(0.038)$

$-6.982 * * *$

(0.297)

Yes

Yes

0.082

7,756

$0.087 * * *$

(0.025)

$0.906^{* *}$

(0.431)

$1.052 * * *$

(0.036)

0.411

(1.200)

0.108 **

(0.055)

$-0.074$

(0.060)

$6.973 * * *$
$(0.313)$

Yes

Yes

41,606

10,202

$$
\text { PSM }
$$

PSM

$$
\mathrm{N}=1
$$

$\mathrm{PSM}$
$\mathrm{N}=2$

PSM

(W/o replacement)

(3)

$0.126^{* * *}$

(0.034)

$0.091 * * *$

(0.021)

0.522

$(0.355)$

$1.093 * * *$
$(0.028)$

0.532

(0.990)

$0.121 * * *$

(0.042)

$-0.084 *$

(0.048)

$-7.096^{* * *}$

Yes

60,540

0.111

10,761

$\mathrm{N}=2 \quad \mathrm{~N}=3$

(4)

$\begin{array}{cc}(4) & (5) \\ 0.156^{* * *} & 0.154^{* * *}\end{array}$

(0.033) (0.029)

$0.081^{* * *} \quad 0.070 * *$

$(0.021) \quad(0.018)$

$0.787 * * \quad 0.545 *$

(0.347) (0.305)

$1.084 * * * \quad 1.088^{* * *}$

(0.028) (0.024)

$0.934 \quad 0.651$

$(0.977) \quad(0.865)$

$0.036 \quad 0.003$

$(0.047) \quad(0.041)$

$-0.055 \quad-0.010$

$(0.052) \quad(0.048)$

$\begin{array}{cr}-6.831^{* * *} & -6.638^{* *} \\ (0.252) & (0.224)\end{array}$

Yes Yes

Yes Yes

$61,377 \quad 77,419$

$0.107-0.110$

$\begin{array}{ll}11,782 & 12,553\end{array}$




\section{Table 7. Heckman Selection, IV Approach}

This table reports regression estimates of the relation between earnings management and listing status. The dependent variables are DLLPs, NDLLPs and PDLLPs and the sample period is from 1986:Q1 to 2013:Q4. The main independent variable is Listing. Model (1) reports the Heckman first step. Model (2) reports the Heckman second step with the inclusion of IMR and interaction term Listing *IMR. Model (3) reports the first step of the IV process. Model (4) reports the second step of the IV process. All financial variables are winsorized at the $1 \%$ and $99 \%$ levels. ***,**, indicate significance at the $1 \%, 5 \%$, and $10 \%$ level respectively. Standard errors are clustered at the bank level. Numbers in parentheses are t-statistics.

\begin{tabular}{|c|c|c|c|c|}
\hline \multirow{3}{*}{ 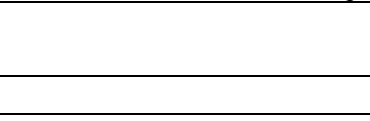 } & \multicolumn{2}{|c|}{ Heckman } & \multicolumn{2}{|c|}{ IV } \\
\hline & First Stage & Second Stage & First Stage & Second Stage \\
\hline & $(1)$ & $(2)$ & (3) & $(4)$ \\
\hline Listing & & $\begin{array}{c}0.310 * * * \\
(0.086)\end{array}$ & & $\begin{array}{c}10.363 * * * \\
(1.225)\end{array}$ \\
\hline Size & $\begin{array}{c}0.527 * * * \\
(0.003)\end{array}$ & $\begin{array}{c}0.055^{*} * * \\
(0.016)\end{array}$ & $\begin{array}{c}0.100 * * * \\
(0.004)\end{array}$ & $\begin{array}{c}-0.959 * * * \\
(0.123)\end{array}$ \\
\hline Capital & $\begin{array}{c}-4.271 * * * \\
(0.114)\end{array}$ & $\begin{array}{l}0.314^{*} \\
(0.178)\end{array}$ & $\begin{array}{c}0.409 * * * \\
(0.058)\end{array}$ & $\begin{array}{c}-3.716^{* * *} \\
(0.524)\end{array}$ \\
\hline Dummy Loss & $\begin{array}{c}0.235 * * * \\
(0.013)\end{array}$ & $\begin{array}{c}1.063 * * * \\
(0.012)\end{array}$ & $\begin{array}{c}0.020 * * * \\
(0.002)\end{array}$ & $\begin{array}{c}0.827 * * * \\
(0.028)\end{array}$ \\
\hline Premanaged earnings & $\begin{array}{c}11.521^{* * *} \\
(0.381)\end{array}$ & $\begin{array}{c}0.665 \\
(0.456)\end{array}$ & $\begin{array}{c}0.115 \\
(0.095)\end{array}$ & $\begin{array}{c}-0.916^{*} \\
(0.482)\end{array}$ \\
\hline Fed & $\begin{array}{c}0.235^{* * *} * \\
(0.010)\end{array}$ & $\begin{array}{c}0.016 \\
(0.027)\end{array}$ & $\begin{array}{c}0.033 * * * \\
(0.011)\end{array}$ & $\begin{array}{c}-0.307 * * * \\
(0.048)\end{array}$ \\
\hline OCC & $\begin{array}{c}-0.058 * * * \\
(0.010)\end{array}$ & $\begin{array}{l}-0.018 \\
(0.030)\end{array}$ & $\begin{array}{l}-0.010 \\
(0.012)\end{array}$ & $\begin{array}{c}0.085 * * * \\
(0.032)\end{array}$ \\
\hline Asset growth & $\begin{array}{c}0.327 * * * \\
(0.057)\end{array}$ & & & \\
\hline Household stock ownership & $\begin{array}{c}0.473 * * * \\
(0.033)\end{array}$ & & $\begin{array}{c}0.040^{* *} \\
(0.016)\end{array}$ & \\
\hline$I M R$ & & $\begin{array}{l}-0.017 \\
(0.067)\end{array}$ & & \\
\hline Listing*IMR & & $\begin{array}{c}-0.107 * * \\
(0.049) \\
\end{array}$ & & \\
\hline Constant & $\begin{array}{c}-7.563 * * * \\
(0.038)\end{array}$ & $\begin{array}{c}-6.324 * * * \\
(0.179)\end{array}$ & $\begin{array}{c}-1.201^{* * *} \\
(0.053)\end{array}$ & $\begin{array}{c}5.624 * * * \\
(1.447)\end{array}$ \\
\hline BFE & & Yes & Yes & Yes \\
\hline QFE & Yes & Yes & Yes & Yes \\
\hline Observations & 293,777 & 274,100 & 314,511 & 272,564 \\
\hline R-squared & & 0.101 & 0.100 & 0.100 \\
\hline Number of Banks & & 14,644 & 15,427 & 14,682 \\
\hline
\end{tabular}




\section{Table 8. Bank Discretionary LLPs During Financial Crises}

This table reports regression estimates of the relation between bank' earnings management and listing status during the financial crises. The dependent variables are DLLPs, NDLLPs and PDLLPS and the sample period is from 1986:Q1 to 2013:Q4. The main independent variables are listing status, Fi Crises, Bk Crises, and Mk Crises. The construction of the financial crisis periods follows Berger and Bouwman (2013). All regressions include bank and time (quarter) fixed effects. All financial variables are winsorized at the $1 \%$ and $99 \%$ levels. $* * *, * * *$ indicate significance at the $1 \%, 5 \%$, and $10 \%$ level respectively. Standard errors are clustered at the bank level. Numbers in parentheses are t-statistics.

\begin{tabular}{|c|c|c|c|c|c|c|c|c|c|c|c|c|}
\hline & \multicolumn{4}{|c|}{$D L L P \mathrm{~s}$} & \multicolumn{4}{|c|}{ NDLLPs } & \multicolumn{4}{|c|}{$\mathrm{PDLLP \textrm {s }}$} \\
\hline & Fi_Cris & $\mathrm{Bk}$ _Cris & Mk_Cris & Both & Fi_Cris & Bk_Cris & Mk_Cris & Both & Fi_Cris & Bk_Cris & Mk_Cris & Both \\
\hline & (1) & (2) & (3) & (4) & $(5)$ & (6) & (7) & $(8)$ & (9) & (10) & (11) & (12) \\
\hline Listing & $\begin{array}{c}0.102 * * * \\
(0.015)\end{array}$ & $\begin{array}{c}0.096 * * * \\
(0.014)\end{array}$ & $\begin{array}{c}0.112 * * * \\
(0.014)\end{array}$ & $\begin{array}{c}0.104 * * * \\
(0.015)\end{array}$ & $\begin{array}{c}0.145^{* * *} \\
(0.016)\end{array}$ & $\begin{array}{c}0.137 * * * \\
(0.015)\end{array}$ & $\begin{array}{c}0.134 * * * \\
(0.015)\end{array}$ & $\begin{array}{c}0.145 * * * \\
(0.016)\end{array}$ & $\begin{array}{c}0.033 \\
(0.022)\end{array}$ & $\begin{array}{l}0.037 * \\
(0.022)\end{array}$ & $\begin{array}{c}0.088 * * * \\
(0.021)\end{array}$ & $\begin{array}{l}0.040^{*} \\
(0.022)\end{array}$ \\
\hline Listing*Fi_Crises & $\begin{array}{c}0.003 \\
(0.010)\end{array}$ & & & & $\begin{array}{c}-0.046^{* * * *} \\
(0.011)\end{array}$ & & & & $\begin{array}{c}0.118 * * * \\
(0.017)\end{array}$ & & & \\
\hline Listing*Bk_Crises & & $\begin{array}{c}0.037 * * * \\
(0.012)\end{array}$ & & $\begin{array}{c}0.031 * * \\
(0.012)\end{array}$ & & $\begin{array}{c}-0.044 * * * \\
(0.013)\end{array}$ & & $\begin{array}{c}-0.049 * * * \\
(0.013)\end{array}$ & & $\begin{array}{c}0.177 * * * \\
(0.020)\end{array}$ & & $\begin{array}{c}0.175 * * * \\
(0.020)\end{array}$ \\
\hline Listing*Mk_Crises & & & $\begin{array}{c}-0.052^{* * *} \\
(0.016)\end{array}$ & $\begin{array}{c}-0.046^{* * * *} \\
(0.016)\end{array}$ & & & $\begin{array}{c}-0.032 * * \\
(0.016)\end{array}$ & $\begin{array}{c}-0.042 * * \\
(0.016)\end{array}$ & & & $\begin{array}{c}-0.061 * * \\
(0.029)\end{array}$ & $\begin{array}{l}-0.017 \\
(0.029)\end{array}$ \\
\hline Size & $\begin{array}{c}0.059 * * * \\
(0.008)\end{array}$ & $\begin{array}{c}0.060 * * * \\
(0.008)\end{array}$ & $\begin{array}{c}0.060 * * * \\
(0.008)\end{array}$ & $\begin{array}{c}0.060 * * * \\
(0.008)\end{array}$ & $\begin{array}{c}0.105^{* * *} \\
(0.009)\end{array}$ & $\begin{array}{c}0.105 * * * \\
(0.009)\end{array}$ & $\begin{array}{c}0.105 * * * \\
(0.009)\end{array}$ & $\begin{array}{c}0.105 * * * \\
(0.009)\end{array}$ & $\begin{array}{c}-0.032 * * * \\
(0.012)\end{array}$ & $\begin{array}{c}-0.031 * * * \\
(0.012)\end{array}$ & $\begin{array}{c}-0.030 * * * \\
(0.012)\end{array}$ & $\begin{array}{c}-0.031^{* * * *} \\
(0.012)\end{array}$ \\
\hline Capital & $\begin{array}{c}0.029 \\
(0.132)\end{array}$ & $\begin{array}{c}0.028 \\
(0.132)\end{array}$ & $\begin{array}{c}0.022 \\
(0.132)\end{array}$ & $\begin{array}{c}0.022 \\
(0.132)\end{array}$ & $\begin{array}{c}0.904 * * * \\
(0.140)\end{array}$ & $\begin{array}{c}0.913 * * * \\
(0.141)\end{array}$ & $\begin{array}{c}0.906^{* * *} \\
(0.140)\end{array}$ & $\begin{array}{c}0.905^{* * *} \\
(0.140)\end{array}$ & $\begin{array}{c}-0.690 * * * \\
(0.192)\end{array}$ & $\begin{array}{c}-0.705 * * * \\
(0.192)\end{array}$ & $\begin{array}{c}-0.698^{* * *} \\
(0.192)\end{array}$ & $\begin{array}{c}-0.707 * * * \\
(0.192)\end{array}$ \\
\hline Dummy Loss & $\begin{array}{c}1.062 * * * \\
(0.008)\end{array}$ & $\begin{array}{c}1.062 * * * \\
(0.008)\end{array}$ & $\begin{array}{c}1.063 * * * \\
(0.008)\end{array}$ & $\begin{array}{c}1.062 * * * \\
(0.008)\end{array}$ & $\begin{array}{c}0.155^{* * *} \\
(0.012)\end{array}$ & $\begin{array}{c}0.155^{* * *} * \\
(0.012)\end{array}$ & $\begin{array}{c}0.155^{* * *} * \\
(0.012)\end{array}$ & $\begin{array}{c}0.155^{* * *} * \\
(0.012)\end{array}$ & $\begin{array}{c}1.648 * * * \\
(0.010)\end{array}$ & $\begin{array}{c}1.648 * * * \\
(0.010)\end{array}$ & $\begin{array}{c}1.650 * * * \\
(0.010)\end{array}$ & $\begin{array}{c}1.648^{* * *} \\
(0.010)\end{array}$ \\
\hline Pre- earnings & $\begin{array}{c}1.487 * * * \\
(0.320)\end{array}$ & $\begin{array}{c}1.496 * * * \\
(0.320)\end{array}$ & $\begin{array}{c}1.515 * * * \\
(0.320)\end{array}$ & $\begin{array}{c}1.518 * * * \\
(0.320)\end{array}$ & $\begin{array}{c}-14.428 * * * \\
(0.379)\end{array}$ & $\begin{array}{c}-14.460 * * * \\
(0.379)\end{array}$ & $\begin{array}{c}-14.418^{* * *} \\
(0.379)\end{array}$ & $\begin{array}{c}-14.432 * * * \\
(0.379)\end{array}$ & $\begin{array}{c}16.150 * * * \\
(0.439)\end{array}$ & $\begin{array}{c}16.195^{* * *} \\
(0.439)\end{array}$ & $\begin{array}{c}16.197 * * * \\
(0.439)\end{array}$ & $\begin{array}{c}16.201 * * * \\
(0.439)\end{array}$ \\
\hline Fed & $\begin{array}{c}0.022 \\
(0.019)\end{array}$ & $\begin{array}{c}0.022 \\
(0.019)\end{array}$ & $\begin{array}{c}0.022 \\
(0.019)\end{array}$ & $\begin{array}{c}0.023 \\
(0.019)\end{array}$ & $\begin{array}{c}0.013 \\
(0.019)\end{array}$ & $\begin{array}{c}0.013 \\
(0.019)\end{array}$ & $\begin{array}{c}0.013 \\
(0.019)\end{array}$ & $\begin{array}{c}0.013 \\
(0.019)\end{array}$ & $\begin{array}{c}0.035 \\
(0.030)\end{array}$ & $\begin{array}{c}0.037 \\
(0.030)\end{array}$ & $\begin{array}{c}0.036 \\
(0.030)\end{array}$ & $\begin{array}{c}0.037 \\
(0.030)\end{array}$ \\
\hline OCC & $\begin{array}{c}-0.007 \\
(0.023) \\
\end{array}$ & $\begin{array}{c}-0.008 \\
(0.023) \\
\end{array}$ & $\begin{array}{c}-0.008 \\
(0.023) \\
\end{array}$ & $\begin{array}{l}-0.009 \\
(0.023) \\
\end{array}$ & $\begin{array}{l}-0.009 \\
(0.022) \\
\end{array}$ & $\begin{array}{c}-0.008 \\
(0.022) \\
\end{array}$ & $\begin{array}{l}-0.009 \\
(0.022) \\
\end{array}$ & $\begin{array}{l}-0.009 \\
(0.022) \\
\end{array}$ & $\begin{array}{c}0.001 \\
(0.034) \\
\end{array}$ & $\begin{array}{c}-0.003 \\
(0.034) \\
\end{array}$ & $\begin{array}{c}0.002 \\
(0.034) \\
\end{array}$ & $\begin{array}{c}-0.003 \\
(0.034) \\
\end{array}$ \\
\hline Constant & $\begin{array}{c}6.396^{* * *} \\
(0.100)\end{array}$ & $\begin{array}{c}-6.397 * * * \\
(0.100)\end{array}$ & $\begin{array}{c}-6.399 * * * \\
(0.100)\end{array}$ & $\begin{array}{c}-6.400 * * * \\
(0.100)\end{array}$ & $\begin{array}{c}-6.863 * * * \\
(0.104)\end{array}$ & $\begin{array}{c}-6.861^{* * *} \\
(0.104)\end{array}$ & $\begin{array}{c}-6.867 * * * \\
(0.104)\end{array}$ & $\begin{array}{c}-6.863 * * * \\
(0.104)\end{array}$ & $\begin{array}{c}-5.437 * * * \\
(0.141)\end{array}$ & $\begin{array}{c}-5.442 * * * \\
(0.141)\end{array}$ & $\begin{array}{c}-5.462 * * * \\
(0.141)\end{array}$ & $\begin{array}{c}-5.444 * * * \\
(0.141)\end{array}$ \\
\hline BFE & Yes & Yes & Yes & Yes & Yes & Yes & Yes & Yes & Yes & Yes & Yes & Yes \\
\hline QFE & Yes & Yes & Yes & Yes & Yes & Yes & Yes & Yes & Yes & Yes & Yes & Yes \\
\hline Observations & 778,860 & 778,860 & 778,860 & 778,860 & 486,360 & 486,360 & 486,360 & 486,360 & 292,500 & 292,500 & 292,500 & 292,500 \\
\hline R-squared & 0.086 & 0.086 & 0.086 & 0.086 & 0.044 & 0.044 & 0.043 & 0.044 & 0.179 & 0.179 & 0.179 & 0.179 \\
\hline Number of Banks & 15,193 & 15,193 & 15,193 & 15,193 & 14,889 & 14,889 & 14,889 & 14,889 & 14,900 & 14,900 & 14,900 & 14,900 \\
\hline
\end{tabular}




\section{Table 9. Discretionary LLPs of Public Banks with Different Qualities of Governance}

This table presents $D L L P$ s of public firms with different qualities of governance. We classify public banks as high corporate governance quality as banks with top quartile corporate governance variables (institutional ownership, institutional block ownership, LT institutional investors) and with bottom quartile of E-Index. Vice versa, with banks with low corporate governance. ***,**,* indicate significance at the $1 \%, 5 \%$, and $10 \%$ level respectively.

\begin{tabular}{|c|c|c|c|c|c|c|c|}
\hline & & & Mean & & & Medi & \\
\hline & & $\begin{array}{c}\text { Low CG } \\
(1)\end{array}$ & $\begin{array}{c}\text { High CG } \\
(2)\end{array}$ & $\begin{array}{c}\text { T-test } \\
(3)=(2)-(1)\end{array}$ & $\begin{array}{c}\text { Low CG } \\
(4)\end{array}$ & $\begin{array}{c}\text { High CG } \\
(5)\end{array}$ & $\begin{array}{l}\text { Wilcoxin test } \\
(6)=(5)-(4)\end{array}$ \\
\hline Institutional Ownership & $D L L P \mathrm{~s}$ & -6.272 & -5.929 & $0.343 * * *$ & -6.176 & -5.877 & $0.299 * * *$ \\
\hline & $\mathrm{N} D L L P \mathrm{~s}$ & -6.300 & -6.024 & $0.275 * * *$ & -6.186 & -5.936 & $0.249 * * *$ \\
\hline & PDLLPs & -6.221 & -5.761 & $0.459 * * *$ & -6.146 & -5.670 & $0.476^{* * *}$ \\
\hline Institutional Block Ownership & $D L L P \mathrm{~s}$ & -6.225 & -6.015 & $0.210 * * *$ & -6.141 & -5.945 & $0.195 * * *$ \\
\hline & $\mathrm{NDLLP \textrm {s }}$ & -6.279 & -6.091 & $0.188 * * *$ & -6.163 & -5.982 & $0.180 * * *$ \\
\hline & $\mathrm{PDLLP \textrm {s }}$ & -6.131 & -5.894 & $0.237 * * *$ & -6.077 & -5.837 & $0.239 * * *$ \\
\hline LT Institutional investors & $D L L P s$ & -6.271 & -6.065 & $0.206^{* * *}$ & -6.179 & -5.999 & $0.180 * * *$ \\
\hline & $\mathrm{N} D L L P \mathrm{~s}$ & -6.310 & -6.129 & $0.181 * * *$ & -6.193 & -6.032 & $0.160 * * *$ \\
\hline & $\mathrm{PDLLP \textrm {s }}$ & -6.205 & -5.950 & $0.255^{* * *}$ & -6.146 & -5.882 & $0.264 * * *$ \\
\hline E-Index & $D L L P \mathrm{~s}$ & -6.943 & -6.329 & $0.614 * * *$ & -6.249 & -6.777 & $-0.52 * * *$ \\
\hline & $\mathrm{N} D L L P \mathrm{~s}$ & -6.972 & -6.395 & $0.577 * * *$ & -6.312 & -6.827 & $-0.51 * * *$ \\
\hline & $\mathrm{PDLLP \textrm {s }}$ & -6.907 & -6.226 & $0.681 * * *$ & -6.004 & -6.733 & $-0.72 * * *$ \\
\hline
\end{tabular}




\section{Table 10. Different Incentives of Discretionary Behaviors}

This table reports regression estimates of the relation between earnings management and listing status. The dependent variables are DLLPs, NDLLPs and PDLLPs and the sample period is from 1986:Q1 to 2013:Q4. In Panel A we report our tests of the Signaling and Capital Management hypotheses. In Panel Be we report our tests of the earnings smoothing hypothesis. The main independent variables are Listing, Dum Signal, Dum Reg, Dum Smooth_1, Dum Smooth_2, and Dum Smooth 3. Models (1)-(3) of Panel A report the results with banks with high incentives to (16) of Panel A indicate the relationship between high incentive to manage capital and DLLPs. Income smoothing incentives are reported in Panel B. All regressions include bank and time (quarter) fixed effects. All financial variables are winsorized at the $1 \%$ and $99 \%$ levels. $* * *, * * *$ indicate significance at the $1 \%, 5 \%$, and $10 \%$ level respectively. Standard errors are clustered at the bank level. Numbers in parentheses are t-statistics.

Panel A: Tests of the Signaling and Capital Management Hypotheses

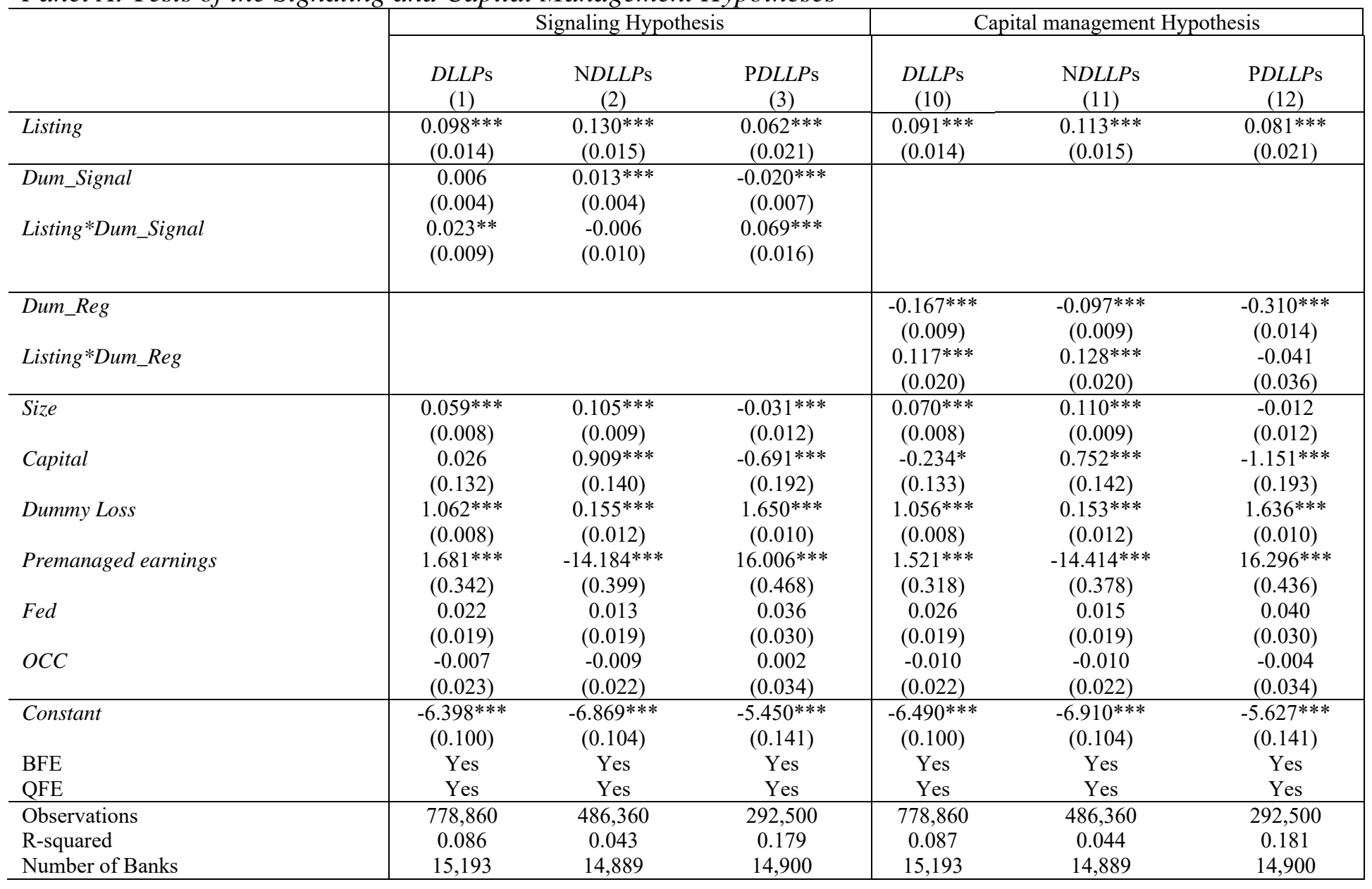


Panel B: Tests of the Earnings Smoothing Hypothesis

\begin{tabular}{|c|c|c|c|c|c|c|c|c|c|}
\hline & \multicolumn{3}{|c|}{ High deviation from average of industry } & \multicolumn{3}{|c|}{ High volatility and high earnings } & \multicolumn{3}{|c|}{ High volatility and low earnings } \\
\hline & $\begin{array}{l}\text { DLLPs } \\
\text { (1) }\end{array}$ & $\begin{array}{l}\text { NDLLPs } \\
\text { (2) }\end{array}$ & $\begin{array}{l}\text { PDLLPs } \\
\text { (3) }\end{array}$ & $\begin{array}{l}\text { DLLPs } \\
\text { (4) }\end{array}$ & $\begin{array}{c}\text { NDLLPs } \\
\text { (5) }\end{array}$ & $\begin{array}{l}\text { PDLLPs } \\
\text { (6) }\end{array}$ & $\begin{array}{l}\text { DLLPs } \\
\text { (7) }\end{array}$ & $\begin{array}{c}\text { NDLLPs } \\
(8)\end{array}$ & $\begin{array}{l}\text { PDLLPs } \\
\text { (9) }\end{array}$ \\
\hline Listing & $\begin{array}{c}0.099 * * * \\
(0.014)\end{array}$ & $\begin{array}{c}0.122 * * * \\
(0.015)\end{array}$ & $\begin{array}{c}0.070 * * * \\
(0.022)\end{array}$ & $\begin{array}{c}0.098 * * * \\
(0.014)\end{array}$ & $\begin{array}{c}0.121 * * * \\
(0.015)\end{array}$ & $\begin{array}{c}0.073 * * * \\
(0.021)\end{array}$ & $\begin{array}{c}0.095^{* * *} * \\
(0.014)\end{array}$ & $\begin{array}{c}0.129 * * * \\
(0.015)\end{array}$ & $\begin{array}{c}0.053 * * \\
(0.021)\end{array}$ \\
\hline Dum_Smooth_1 & $\begin{array}{l}-0.006 \\
(0.005)\end{array}$ & $\begin{array}{c}-0.013 * * \\
(0.005)\end{array}$ & $\begin{array}{c}0.084 * * * \\
(0.008)\end{array}$ & & & & & & \\
\hline Dum_Smooth_2 & & & & $\begin{array}{c}0.100^{* * *} \\
(0.010)\end{array}$ & $\begin{array}{c}0.124 * * * \\
(0.011)\end{array}$ & $\begin{array}{c}0.151^{* * *} \\
(0.015)\end{array}$ & & & \\
\hline Dum_Smooth_3 & & & & & & & $\begin{array}{c}0.080 * * * \\
(0.008)\end{array}$ & $\begin{array}{c}0.150 * * * \\
(0.010)\end{array}$ & $\begin{array}{c}0.051 * * * \\
(0.013)\end{array}$ \\
\hline Listing *Dum_Smooth_1 & $\begin{array}{l}0.019^{*} \\
(0.011)\end{array}$ & $\begin{array}{c}0.032 * * * \\
(0.012)\end{array}$ & $\begin{array}{c}0.020 \\
(0.018)\end{array}$ & & & & & & \\
\hline Listing *Dum_Smooth_2 & & & & $\begin{array}{c}0.057 * * * \\
(0.022)\end{array}$ & $\begin{array}{c}0.092 * * * \\
(0.023)\end{array}$ & $\begin{array}{c}0.044 \\
(0.036)\end{array}$ & & & \\
\hline Listing *Dum_Smooth_3 & & & & & & & $\begin{array}{c}0.045^{* *} \\
(0.021)\end{array}$ & $\begin{array}{c}-0.052 * * \\
(0.024)\end{array}$ & $\begin{array}{c}0.185^{* * *} * \\
(0.032)\end{array}$ \\
\hline Size & $\begin{array}{c}0.059 * * * \\
(0.008)\end{array}$ & $\begin{array}{c}0.104 * * * \\
(0.009)\end{array}$ & $\begin{array}{c}-0.026^{* *} \\
(0.012)\end{array}$ & $\begin{array}{c}0.059^{* * *} \\
(0.008)\end{array}$ & $\begin{array}{c}0.105 * * * \\
(0.008)\end{array}$ & $\begin{array}{c}-0.031 * * * \\
(0.012)\end{array}$ & $\begin{array}{c}0.058^{* * *} \\
(0.008)\end{array}$ & $\begin{array}{c}0.104 * * * \\
(0.008)\end{array}$ & $\begin{array}{c}-0.034 * * * \\
(0.012)\end{array}$ \\
\hline Capital & $\begin{array}{c}0.023 \\
(0.132)\end{array}$ & $\begin{array}{c}0.901 * * * \\
(0.141)\end{array}$ & $\begin{array}{c}-0.566^{* * * *} \\
(0.192)\end{array}$ & $\begin{array}{l}-0.000 \\
(0.132)\end{array}$ & $\begin{array}{c}0.879 * * * \\
(0.140)\end{array}$ & $\begin{array}{c}-0.736^{* * * *} \\
(0.192)\end{array}$ & $\begin{array}{c}0.035 \\
(0.132)\end{array}$ & $\begin{array}{c}0.892 * * * \\
(0.140)\end{array}$ & $\begin{array}{c}-0.675 * * * \\
(0.192)\end{array}$ \\
\hline Dummy Loss & $\begin{array}{c}1.063 * * * \\
(0.008)\end{array}$ & $\begin{array}{c}0.156^{* * *} \\
(0.012)\end{array}$ & $\begin{array}{c}1.647 * * * \\
(0.010)\end{array}$ & $\begin{array}{c}1.052 * * * \\
(0.008)\end{array}$ & $\begin{array}{c}0.136^{* * *} \\
(0.012)\end{array}$ & $\begin{array}{c}1.639 * * * \\
(0.010)\end{array}$ & $\begin{array}{c}1.055^{* * *} * \\
(0.008)\end{array}$ & $\begin{array}{c}0.133 * * * \\
(0.012)\end{array}$ & $\begin{array}{c}1.645^{* * * *} \\
(0.010)\end{array}$ \\
\hline Premanaged earnings & $\begin{array}{c}1.554 * * * \\
(0.357)\end{array}$ & $\begin{array}{c}-14.243^{* * *} \\
(0.424)\end{array}$ & $\begin{array}{c}14.155^{* * * *} \\
(0.481)\end{array}$ & $\begin{array}{c}0.254 \\
(0.332)\end{array}$ & $\begin{array}{c}-16.128^{* * *} \\
(0.399)\end{array}$ & $\begin{array}{c}14.483^{* * *} * \\
(0.457)\end{array}$ & $\begin{array}{c}2.708^{* * *} * \\
(0.343)\end{array}$ & $\begin{array}{c}-12.456^{* * *} \\
(0.396)\end{array}$ & $\begin{array}{c}17.311^{* * *} \\
(0.475)\end{array}$ \\
\hline Fed & $\begin{array}{c}0.022 \\
(0.019)\end{array}$ & $\begin{array}{c}0.013 \\
(0.019)\end{array}$ & $\begin{array}{c}0.035 \\
(0.030)\end{array}$ & $\begin{array}{l}0.020 \\
(0.019)\end{array}$ & $\begin{array}{c}0.011 \\
(0.019)\end{array}$ & $\begin{array}{c}0.032 \\
(0.030)\end{array}$ & $\begin{array}{c}0.022 \\
(0.019)\end{array}$ & $\begin{array}{c}0.013 \\
(0.019)\end{array}$ & $\begin{array}{c}0.034 \\
(0.030)\end{array}$ \\
\hline OCC & $\begin{array}{l}-0.007 \\
(0.023)\end{array}$ & $\begin{array}{l}-0.009 \\
(0.022)\end{array}$ & $\begin{array}{c}0.002 \\
(0.034)\end{array}$ & $\begin{array}{l}-0.007 \\
(0.022)\end{array}$ & $\begin{array}{l}-0.009 \\
(0.022)\end{array}$ & $\begin{array}{c}0.003 \\
(0.034)\end{array}$ & $\begin{array}{l}-0.008 \\
(0.022)\end{array}$ & $\begin{array}{l}-0.009 \\
(0.022)\end{array}$ & $\begin{array}{c}0.001 \\
(0.034)\end{array}$ \\
\hline Constant & $\begin{array}{c}-6.394 * * * \\
(0.100)\end{array}$ & $\begin{array}{c}-6.858^{* * *} \\
(0.104)\end{array}$ & $\begin{array}{c}-5.490 * * * \\
(0.142)\end{array}$ & $\begin{array}{c}-6.372 * * * \\
(0.100)\end{array}$ & $\begin{array}{c}-6.831 * * * \\
(0.103)\end{array}$ & $\begin{array}{c}-5.425 * * * \\
(0.141)\end{array}$ & $\begin{array}{c}-6.393 * * * \\
(0.099)\end{array}$ & $\begin{array}{c}-6.883 * * * \\
(0.103)\end{array}$ & $\begin{array}{c}-5.433 * * * \\
(0.141)\end{array}$ \\
\hline $\begin{array}{l}\text { BFE } \\
\text { OFE }\end{array}$ & $\begin{array}{l}\text { Yes } \\
\text { Yes }\end{array}$ & $\begin{array}{l}\text { Yes } \\
\text { Yes }\end{array}$ & $\begin{array}{l}\text { Yes } \\
\text { Yes }\end{array}$ & $\begin{array}{l}\text { Yes } \\
\text { Yes }\end{array}$ & $\begin{array}{l}\text { Yes } \\
\text { Yes }\end{array}$ & $\begin{array}{l}\text { Yes } \\
\text { Yes }\end{array}$ & $\begin{array}{l}\text { Yes } \\
\text { Yes }\end{array}$ & $\begin{array}{l}\text { Yes } \\
\text { Yes }\end{array}$ & $\begin{array}{l}\text { Yes } \\
\text { Yes }\end{array}$ \\
\hline $\begin{array}{l}\text { Observations } \\
\text { R-squared } \\
\text { Number of Banks }\end{array}$ & $\begin{array}{c}778,860 \\
0.086 \\
15,193\end{array}$ & $\begin{array}{c}486,360 \\
0.043 \\
14,889\end{array}$ & $\begin{array}{c}292,500 \\
0.180 \\
14,900\end{array}$ & $\begin{array}{c}778,860 \\
0.087 \\
15,193\end{array}$ & $\begin{array}{c}486,360 \\
0.044 \\
14,889\end{array}$ & $\begin{array}{c}292,500 \\
0.180 \\
14,900\end{array}$ & $\begin{array}{c}778,860 \\
0.086 \\
15,193\end{array}$ & $\begin{array}{c}486,360 \\
0.044 \\
14,889\end{array}$ & $\begin{array}{c}292,500 \\
0.179 \\
14,900\end{array}$ \\
\hline
\end{tabular}

